\title{
O Projeto do Codigo Criminal perante a critica
}

\section{Alcantara Machado}

Proponho-me a dar uma impressão da maneira por que vem sendo recebido o projeto de minha autoria.

Poucos os que dele se ocuparam e relativamente diminutos os reparos que suscitou. Se me desvairasse a vaidade, sentir-me-ia satisfeito. Tudo, porém, demonstra que a parcimonia das criticas dignas desse nome não é indice da perfeição da obra, e sim testemunho de desinteresse. Haverá que atribuir essa indiferença á preguiça mental? Ou será o caso de imputa-la á convicção reinante de que não existe sincero empenho em levar a cabo a reforma completa e orgânica da legislação vigente? A experiencia destes ultimos quarenta anos tem ensinado, com efeito, que não ha pressa em pôr abaixo o edificio arruinado a que serve de arcabouço o codigo de 1890. Prefere-se remendalo e retoca-lo constantemente, escorando aqui uma parede, tomando ali uma goteira, acrescentando acolá uma dependencia. Daí, a proliferação de dispositivos extravagantes, para desespero de uns e gáudio de outros. Não era sem razão que no banquete anual dos advogados ingleses se bebia antigamente "á gloriosa incerteza da lei.

Seja como fôr, julgo-me no dever de resumir os debates escassos, que se hão travado em torno do projeto, cuja responsabilidade me incumbe. 


\section{A LINGUAGEM}

Só elogios tem merecido a linguagem em que está vasado o trabalho.

Escreve, a propósito, Costa e Silva: “A leitura do ante-projeto deixou-me a mais lisonjeira impressão relativamente á linguagem em que ele se acha redigido. Sob esse ponto de vista é patente a sua superioridade, quando o cotejamos com o da lavra do desembargador Sá Pereira, tanto antes como depois da revisão. A linguagem de um codigo deve ser correta, concisa e clara. Essas tres qualidades se descobrem, ao primeiro relance de olhos, no anteprojeto" Do mesmo parecer é Carlos Xavier: "estilo elegante, conciso, quasi diáfano". Madureira DE PINHo declara-o "redigido em fórma lapidar, sem demasiada pretensão literaria (o que muito prejudicou o anterior projeto)" Para MotTa Filho o codigo italiano é, neste particular, "evidentemente inferior ao projeto. que apresenta uma linguagem muito mais segura e muito mais cristalina... escorreita e simples". Igualmente lisongeira é a opinião de IruReta Goyena: "o projeto nos seduziu desde logo pela transparencia absoluta de suas fórmulas, por sua insuperavel precisão, pela singeleza do estilo, pela sobriedade racional".

Isso não impediu que se fizessem restrições, não á limpeza e correção gramatical do texto, mas á propriedade de algumas das expressões empregadas.

1) A começar pelo nome.

Motra Filho formulou elegantemente a sua objeção: "Se por essa obra sabemos que a pena é a razão de ser de um direito penal; se todos os cuidados, todos os institutos, todos os dispositivos, toda a vida, enfim, do codigo se faz 
em torno da atividade punitiva; se sabemos, mesmo pela historia do direito, que foi para dar á pena o seu verdadeiro sentido, que surgiu o direito penal, porque chamar a um codigo que tem essa orientação codigo criminal?"

Por varios motivos igualmente ponderosos.

Primeiro, por uma razão de ordem lógica. A idéa do crime precede manifestamente á da penalidade.

Segundo, porque se trata de codificação, que só compreende parte da legislação penal. E' o argumento de FLoRIAN. Como se poderá dar o nome de penal a um código, que deixa de parte o direito penal militar, o direito penal maritimo, o direito penal financeiro, um sem numero de dispositivos penais constantes das leis mais variadas?

Terceiro, porque, a exemplo de todos os códigos e de todos os projetos de reforma penal, com exceção do argentino de 1937, o projeto brasileiro de 1938 adota a distinção entre pena e medida de segurança, regulando-as e aplicando-as diferentemente. Tanto basta para que se deva denominar "criminal", e não "penal" E' o que acentua GrovaNovitch (em Il Codice Rocco e le recenti codificazioni penali, p. 40), quando escreve que a denominação "código penal" estará em contradição com o conteudo, sempre que as medidas de seguranca ocuparem no corpo da lei um logar de importancia igual ao das penas. E' o que reconhecem os proprios criminalistas, que são pela identidade fundamental entre os dois institutos. Eis, por exemplo, o que diz Bruno Cassinella (Positivismo e misure di sicurezza, em Scritti tecnici-pratici sulla nuova legislazione penale, II, 1939, p. 32) : com a adoção de taes medidas, "não ha mais falar de direito penal, e sim de direito criminal, isto é, de um direito que não mais se carateriza pelas penas, mas tambem por outras medidas de reação contra o direito" Tambem Enrico Altavilla (Lineamenti di diritto criminale, p. 356) increpa aos autores do codigo italiano não lhe haverem chamado "codigo criminal", uma vez que perfilharam a teoria mixta ou intermédia, colocando a par da pena, como figura distinta, a medida de segurança. Isso 
mesmo ele reafirma em artigo, com que honra a nossa "Revista"

Quarto, porque o projeto reata neste lance a nossa tradição, restaurando o nome por que foi conhecido entre nós, durante sessenta anos, mercê do codigo de 1930, o corpo das leis repressivas. Não se alegue tratar-se de "um habito abandonado ha meio século, inteiramente fóra do jeito da geração atual" Porque a verdade é que á atual geração não pode ser estranha a sobrevivencia teimosa da denominação que propugno. Data de quatro anos apenas a revogação da lei constitucional de 1891, que á União atribuia competencia para legislar sobre o direito criminal da República. Uma das obras didáticas mais conhecidas e manuseadas é o "Direito Criminal" de Lima Drummond. E' nos livros de processo criminal de Joño Mendes Junior e de Galdino de Siqueira, que se continua a aprender essa disciplina. Se quiser conhecer a legislação estadual ainda vigente, ha de o jurista consultar o codigo de processo criminal baiano, trabalho memoravel de Eduardo Espinola, e os do Pará, da Paraiba, do Ceará, de Alagoas, de Mato Grosso; e para se manter a par da jurisprudencia, consultará forçosamente o "Repertorio de Jurisprudencia Criminal", de Edgard Costa, a "Jurisprudencia Criminal", de Viveiros de Castro, a "Revista de Direito Civil, Comercial e Criminal", fundada por Bento de Faria.

Com a delicadeza e a superioridade que o distinguem, Carlos Xavier discorda tambem do nome aventado no projeto Sá Pereira e aceito pelo meu. Parece-lhe que dirimiram a questão as constituições de 1934 e 1937 , onde se confere á União o poder de legislar sobre direito penal. Para mim, todavia, o que houve foi uma ampliação da competencia federal. O estatuto de 1891 não a reconhecia, senão quanto ao direito propriamente criminal. Estenderam-na a toda a materia penal os estatutos posteriores. O certo, porém, que, embora não me convença, o argumento de CarLos Xavier é o único a impressionar-me. Inclinat, non necessitat. 
2) "Do agente" é a epigrafe a que obedece um dos titulos da Parte Geral.

Impugnoll-a Carlos Xavier, por destoante da tradição legislativa. Expliquei não ter sido o simples gosto de inovar, que neste passo me inspirara, mas a consideração de que sob a rubrica "do criminoso" ou "do delinquente", não ha tratar de quem como tal não pode ser considerado, como seja o inimputavel.

Mas (aparteou-me o sr. Hungria) "não é somente por ação que se comete crime, senão tambem por omissão, $e$ omitente não é agente" Em resposta poderia eu perguntar se ha impropriedade em declarar o omitente sujeito ativo do crime. Prefiro dar a palavra a Costa e Silva (Cod. Pen. I, p. 6): "A omissão não representa cousa diferente da ação: é apenas uma modalidade desta. A ciencia e a prática estão de acordo nessa equiparação"

Sofisma, replicam amavelmente, não a mim, mas ao precitado criminalista patricio. Porque? Porque "omitir é não agir. Omissão é inação. Isto é o que dizem todos os dicionarios, sem exceção de um só" É inexato. O que dizem, em substancia, todos os dicionarios é o que se lê no de Caldas Aulete. Que significa omissão? Ação de omitir. E inação? Falta de ação. Aos olhos salta a diferença. Entende-se por inação o fato de não fazer cousa alguma. Por omissão, o de deixar de fazer cousa determinada. Assim é em português, em francês, em italiano, em inglês, em alemão. Assim é na linguagem vulgar e na linguagem do direito. Quem o diz é von Hippel, em seu conhecidissimo livro, traduzido para o italiano sob o titulo de Manuale di Diritto Penale (1936, $\S 30$, p. 142): “Omettere non significa, linguisticamente, il non fare nulla, ma il non fare qualche cosa di determinato, quello cioè, che in un dato caso era possibile e da attendersi. Ciò anche in diritto penale" Quem o repete é Silvio Ranieri (La causalità nel diritto penale, 1936, p. 253): “Omettere, nel campo del diritto penale, non 
è affatto non fare nulla, bensi non svolgere una determinata attività, contrariamente al comando di una norma giuridica, cioè non osservare un comando di agire, mediante il non compimento di un'attività giuridicamente doverosa e possibile, e tenendo cosi un comportamento diverso da quello comandato"

Pode-se, portanto, afirmar, sem receio de contestação honesta, que o omitente é agente.

3) Dispõe $o$ art. $1 .^{\circ}$ não haver crime, sem lei anterior que o qualifique. Observa Costa e Silva: "O crime que a lei qualifica é o crime qualificado, e não o crime em geral” E conclue: “o verbo está a pedir a substituição por outro, que melhor exprima a ideia que se teve em mente"

Nenhuma procedencia tem a censura. Qualificar é atribuir qualidade. A palavra está empregada acertadamente. Vem do codigo de 1830. Mantem-na o de 1890. Adotam-na todos os projetos de reforma. Porque substitui-la? Pouco importa que vulgarmente se digam qualificados certos crimes, quando ocorrem determinadas circunstancias, que lhes agravam a pena. E' o que sucede com o homicidio, por exemplo, no caso do art. $294 \S 10^{\circ}$ da Consolidação. Qualificado tem aí sentido diferente. Dir-se-á corretissimamente que todo ser humano, quando nascido com vida, é qualificado pessoa pelo codigo civil. Não quer isso dizer, todavia, que todo ser humano, nascido com vida, seja pessoa qualificada. .

4) - $O$ ante-projeto mandava computar na pena privativa da liberdade “o tempo da prisão preventiva aqui e no estrangeiro" 0 sr. Hungria achou "o estilo pouco recomendavel". Grande surpresa de minha parte. Veiu afinal a explicação: "não me pareceu muito proprio que o nosso querido Brasil, com os seus oito milhões e meio de quiló metros quadrados, os seus quarenta e cinco milhões de habitantes, os seus quatrocentos trinta anos de historia, o 
grito do Ipiranga, o 15 de novembro, a memoria de Rui Barbosa, etc., fosse designado com o minusculo adverbio "aqui" Um gracejo, evidentemente; e gracejos não se refutam.

5) - Com referencia ao mesmo dispositivo, alegou o sr. Hungria que, em vez de prisão "preventiva", se deveria dizer prisão "provisoria", para compreender a que decorre de flagrante, de pronuncia, de sentença não definitiva.

A arguição é tudo quanto ha de menos plausivel. A prisão preventiva (ensina João Mendes Junior, Processo Criminal, I, p. 371), para o fim que temos em vista, abraça todo o tempo durante o qual um condenado foi privado de sua liberdade, antes de sofrer a sua pena. Chama-se prisão preventiva, professa por seu turno Costa E Silva (Cod. Pen., II, p. 235), a que o imputado sofre antes do julgamento definitivo do processo. Compreende-se nestè conceito (acrescenta ele) a prisão que se efetua em flagrante, isto é, no momento em que o crime é praticado ou quando, logo em seguida, é o delinquente perseguido pelo clamor publico. Mas porque multiplicar citações em abono de verdades elementares?

6) - Madureira de Pinho sugere que, em vez de "epizootia" e "epifitia”, palavras técnicas, ainda não incorporadas á linguagem quotidiana, e por isso de entendimento dificil para o vulgo, o art. 221 use de expressões equivalentes ás do codigo italiano. De acordo. Poderia ser esta a redação: "difundir doença que ataque animaes ou plantas, em carater epidemico, expondo a perigo a economia rural e as riquezas naturaes do paiz"

7) - Para o sr. Prudente de Sigueira carecem de precisão as expressões "surdo-mudo educado" e "não educado". "selvicola adaptado" e "incompletamente adaptado" 
O critico, porém, se esquece de revelar como substitui-las por outras mais adequadas. Aponta o defeito, mas silencia o remedio, o que é pecar contra a caridade.

8) - O egrégio prof. Enrico Altavilla assinala uma inpropriedade, que me escapou, no art. 27 n. II. Aí não caberia, com feito, falar de "agente", mas de "indiciado" ou "acusado"

9) - Ao mesmo crítico se afigura imprecisa a linguagem do projeto, visto que ai se empregam "indiferentemente as expressões "oficial" e "público funcionario", e se desconhece "a noção de encarregado de serviço público ou de quem exerce serviço de pública necessidade" A primeira assertiva é fruto, segundo creio, de um equívoco do censor: não me lembro de ter aludido a oficial, e sim, e sempre, a autoridade e funcionario. Quanto á segunda, parece-me que a materia é antes de direito administrativo do que de direito criminal. Nada custaria, aliás, acrescentar ao projeto um dispositivo que, para os ef eitos penaes, equiparasse aos funcionarios públicos os dos institutos autárquicos e de outros serviços de utilidade pública.

\section{II}

\section{A ORIGINALIDADE}

Acusa-se tão acerba, quanto infundadamente o projeto de ser imitação do código italiano de 1930. A historia se repete. Houve quem acusasse a legislador de 1830 de copiar o codigo napolitano de 1819, o codificador de 1890 de plagiar o codigo Zanardelli de 1889, o projeto Sá Pereira de reproduzir o suiço.

A verdade, entretanto, é que seria simplesmente insensata a preocupação de originalidade absoluta em assunto desta natureza. "Je prends mon bies où je le trouve", ha 
de ser forçosamente o lema de quem empreende, com plena conciencia de suas responsabilidades, uma reforma legislativa. O que manda a sabedoria é que se cotejem as soluções aventadas e que dentre ou fóra delas se procure a que melhor convenha.

Naturalissima a influencia exercida em meu espirito pela vigente codificação italiana.

Obra longamente meditada de alguns dentre os maiores cultores da especialidade, numa terra que os sabedores consideram com justiça a patria do direito criminal, o ultimo codigo penal da Italia é tido por Cuello Calón, da Universidade de Barcelona (Il progetto Rocco nel pensiero giuridico contemporaneo, p. 402), como construção técnica de perfeição tamanha, que constitue modelo impecavel. Tem, além disso, o mérito inapreciavel de se não enfeudar a nenhuma escola. A "Relazione al Re" assinala com razão que a elaboração da lei deve efetuar-se, "non in virtù o in conkemplazione di astratte disquisizioni filosofiche e teoriche, hensi in vista ed in considerazione dei reali bisogni della vita collettiva ossia delle esigenze sociali e delle opportunità e convenienze politiche" Oportunismo, pragmatismo, ecletismo, - pouco importa. E' a oricntação que a prudencia recomenda e que permite acolher o que ha de verdadeiro e proveitoso nas teorias modernas, sem repudiar os postulados tradicionaes do direito repressivo.

Outros motivos, igualmente ponderosos, justificam a influencia, que fui o primeiro a confessar na "Exposição" preliminar do ante-projeto da Parte Geral, e de que nã me pejo, nem me arrependo.

Antes de tudo, os laços espirituaes, que advêm do caráter acentuadamente latino de nossa cultura e que tendem a aumentar com a transfusão cresoente de sangue itálico em veias brasileiras.

Além disso, as afinidades políticas, que se manifestam pelo reforço da autoridade do Estado na presente organi- 
zacão constiłucional de ambos os paizes, e pelo cuidado especial que ambos consagram a certos institutos e bens, como sejam a saude da estirpe, a familia, a economia popular, o credito publico, a probidade na execução dos contratos, imperfeitamente resguardados por outras legislações.

E, por último, e acima de tudo, a excelencia dos resultados da aplicação do código Rocco, resultados que se traduzem pela diminuição quantitativa e pela atenuação qualitativa da criminalidade peninsular. Comprovam-no irrespondivelmente as estatísticas. Vejam-se os dados reunidos e analisados por Diego de Castro (em La Scuola Positiva, julho-agosto de 1936, p. 244 e s.). A partir de 1931, data em que começou a ser executada a reforma, a delinquencia apresenta "uma nítida e admiravel tendencia a decrescer". Decresce o numero de infrações; e, o que é de maior significação, diminuem sobretudo as manifestações mais graves da criminalidade. Aqui está um quadro muitíssimo expressivo:

\section{DIMINUIÇÃO PERCENTUAL DE 1932 A 1935}

\begin{tabular}{|c|c|}
\hline Homicidios consumados & 27 \\
\hline Homicidios tentados & 0,0 \\
\hline esões voluntarias & \\
\hline Infanticidios & 24, \\
\hline Rapinas, extorsões, etc $\ldots \ldots \ldots \ldots, \ldots$ & \\
\hline $\begin{array}{l}\text { Violencias, resistencias, ultrages á auto } \\
\text { ridade } \quad \ldots \ldots \ldots \ldots \ldots \ldots \ldots \ldots \ldots\end{array}$ & \\
\hline Crimes contra a & \\
\hline a incolumidade pública & 19 \\
\hline $\begin{array}{ll}\text { a moralidade } & \text { e os bons } \\
\text { costumes } & \ldots\end{array}$ & 6, \\
\hline
\end{tabular}

Sem embargo de tudo isso, o projeto brasileiro está muito longe de ser cópia ou adaptação da obra italiana. Acompanhou-a em mais de um lance. Dela, porém, se apartou em muitíssimos outros de capital importancia. Tal a opinião de todos os críticos de boa fé, como Carlos Xavier 
e Madureira de Pinho. "Neste passo, disse o último em conferencia proferida no Instituto de Estudos Brasileiros e publicada na respectiva Revista, novembro-dezembro de 1938, p. 60), o projeto abandona o modelo italiano, a que tantas vezes foi fiel, sem jamais descambar na imitação servil e censuravel. Na medida do possivel em obras do gênero, o projeto do emérito penalista se mostra original, ainda que (e isto só lhe serve de abono) não demonstre o amor das originalidades" Diz semelhantemente aquele, no primeiro dos artigos suculentos que a "Revista Judiciaria", do Rio, vem inserindo: "Vê-se, de logo, que, do mesmo modo que a Virgillo de SÁ Pereira servira de luz guiadora o projeto suiço de Stoos, inspirou-se o ilustre criminólogo no Codice Penale Italiano, fruto de cinco anos de elaboração jurídica de Rocco, Massara, Janitti, Falco, e, entre outros, do proprio Ferri, elogiado por Stallybias, Bise, Donnedieu, Kovats, Calón, e que, sem sectarismo, procurou ligar a inovação á tradição. Não se curvou, porém, servilmente. Colheu o que lhe parecia aproveitavel e adaptavel ás realidades brasileiras, diferentes das do regime do "fascio" Mas difere do código italiano, não sómente na divisão e distribuição das materias, classificação de crimes, estabelecimento das penas, como em materia de preterintencionalidade e semi-responsabilidade, na repulsa á dicotomia que separa o crime da contravenção, na regulamentação das medidas de segurança e em diversos pontos substanciaes"

E' o que ressalta do simples cotejo dos textos.

1) - Comecemos pela materia codificada.

Ao contrario do código italiano, o projeto não trata:

- das contravenções;

- nem da pessoa ofendida pelo crime;

- nem das sanções civis;

- nem dos chamados crimes contra a personalidade interna do Estado. 
2) - Agora, a classificação.

Divide-se o código Rocco em tres livros, intitulados "dos crimes em geral”, “dos crimes em particular", e "das contravenções" Em dois livros se divide o projeto brasileiro, correspondentes á Parte Geral e á Parte Especial.

Diferentes são a ordenação da materia e o conteudo das subdivisões.

Assim, quanto á Parte Greral, por exemplo:

- o código italiano trata sucessivamente da lei penal, das penas, do crime, do réo e da pessaa ofendida pelo crime, da modificação, aplicação e cumprimento da pena, da extinção do crime e da pena, das sanções civis, das medidas administrativas de segurança; enquanto que, seguindo ordem quasi inteiramente diversa, o projeto se ocupa da aplicação da lei criminal, do crime, do agente, das penas. das medidas de seguranca, do regime da menoridade, da ação criminal;

- o primeiro divide as penas em principaes e acessorias, ao passo que estas são consideradas pelo projeto como efeitos necessarios ou eventuaes da condenação;

- um estabelece as penas de morte, ergástulo, reclusão, multa e ressarcimento; e o outro as de morte, reclusão, detenção, segregação e multa;

- manda o código aumentar a pena, em se tratando de criminosos por tendencia, reincidentes, habituaes e profissionaes; e o projeto submete-os apenas a medidas de segurança, e não distingue o profissionalismo da habitualidade;

- o primeiro determina que os delinquentes de imputabilidade restrita cumpram em estabelecimento comum a pena detentiva a que forem condenados e sejam depois submetidos á medida de segurança adequada; ao passo que o segundo preceitua a conversão da pena detentiva em segregação, a ser execulada em estabelecimento especial de tratamento e custódia; 
- aquele fixa em quatorze anos a menoridade penal, e o ultimo em dezoito;

-o legislador italiano inclue entre as penas acessorias a interdição legal e a perda da capacidade de testar e a nulidade do testamento feito antes da condenação, cousas que o projeto brasileiro desconhece;

-- o confisco figura entre as medidas de segurança no código e entre os efeitos da sentença no projeto;

- este enumera entre as medidas de segurança a clau: sura do estabelecimento, o que naquele não se verifica.

Ver-se-á, examinando a Parte Especial, que o projeto brasileiro diverge rasgadamente do código Rocco, em um sem numero de pontos da maior importancia. Assim, por exemplo, no que respeita:

- aos crimes contra a organização política e social, de que se não ocupa;

- aos crimes de perigo comum, que classifica entre os crimes contra a incolumidade pública, ao contrario do outro, que os encarta nos delitos contra a tranquilidade pública;

- ao duelo, que está entre as infrações contra a incolumidade pessoal, enquanto que no italiano se encontra definido com delito contra a administração da justiça;

- á receptação que, em vez do que se vê no italiano, aparece em capitulo especial, a par de outros crimes afins com os patrimoniaes;

- aos crimes contra a honra, disciplinados de modo muito diferente do que está no suposto modelo;

- aos crimes contra a saude da estirpe e contra a moralidade pública e os bons costumes, em que são grandes e profundas as divergencias.

Só por aleivosia ou com desconhecimento de causa se poderá, portanto, inquinar o projeto de imitação ou cópia da construção fascista. $O$ que nele se percebe, como se per- 
cebe nos projetos argentino, chileno, francês e nos códigos recentes da China e do Uruguai, é o vinco deixado no espírito de quem os elaborou pela codificação italiana. Não teve dúvida em confessá-lo Eusebio Gomez, que com Eduardo Coll se incumbiu da projetada reforma penal argentina (Rivista Penale, julho de 1938, p. 791): "Sarebbe ingiusto non dichiarare l'enorme influenza che, nella elaborazione del nostro progetto, ha avuto il diritto penale italiano, sia come scienza sia come legge positiva. Il fatto non può sorprendere coloro che conoscano, anche sommariamente, le manifestazioni di cultura giuridico-penale del nostro paese. Gli autori italiani, senza distinzione di scuole, furono oggetto costante della nostra ammirazione, e il progetto argentino, che concreta nei suoi articoli i concetti fondamentali della scuola positiva, è l'omaggio più completo che possiamo rendere a coloro che furono e continueranno ad essere i nostri preclari maestri"

\section{III}

\section{A ESTRUTURA}

Várias observações despertou o projeto neste particular.

1) - Sob a epígrafe "do agente" (ponderou Costa E Silva), o ante-projeto reunia grande número de dispositivos, que reclamavam, para maior clareza, a subdivisão do título. O reparo foi tomado em consideração no texto definitivo, onde os preceitos se distribuem por tres capítulos.

2) - Carlos Xavier e Madureira de Pinho não se mostraram favoraveis á eliminação das contravenções.

Disse o último: "Se de um lado é irrecusavel a procedencia do argumento, quanto á dificuldade no encontrar criterio e base teóricos para a diferenciação entre contravenções e crimes, de outro lado, evidente e solar é a verdade que de todo em todo diverso é o juizo de valor que 
se formula do crime e da contravenção, do criminoso e do contraventor. Está essa diversidade de juizo tão arraigada na mentalidade popular, por obra da tradição de nossas leis penaes, que não vejo porque abandoná-la, sem o risco, sempre elevante, de com isso enfraquecer, no público, o rigor da sanção moral em que importa o epíteto, o labéo de criminosos" Se não me engano, o argumento é contraproducente. Vem em reforço dos que pensam que a materia de contravenções deve constituir objeto de legislação distinta, porque a propria conciencia pública repele a sua equiparação ao crime.

Carlos Xavier não se declara adversario da solução adotada pelo projeto e abonada pelos códigos argentino, colombiano, russo, norueguês e húngaro. Anuncia, entretanto, restrições á entrega da totalidade das infrações policiaes ás legislações da União, dos Estados e dos Municipios. Direi desde logo que, de uma parte, não ha negar aos Estados e aos Municipios a competencia em questão, consectario lógico do poder de policia; e, de outro lado, que, em verdade, muito pouco terão eles de regular, uma vez que muitas dentre as contravenções de maior gravidade passam a ser consideradas crimes, de acordo com o projeto, e as outras serão forçosamente contempladas no código policial da União.

Em contraposição, demonstrou Candido Motra Filho (Revista da Faculdade de Direito de S. Paulo, XXXIV, p. 178) que, em favor da orientação do projeto, neste lance, concorrem o criterio de ordem técnico-juridica, o criterio de ordem social e o criterio de ordem política. Nada tenho a acrescentar a essa argumentação, que se me afigura decisiva.

3) - Depois de cuidar dos delitos contra a Nação, os Estados estrangeiros e os direitos políticos dos cidadãos, determina o projeto, em seu art. 150, que se regularão por lei 
especial os crimes contra a organização política e social do Estado.

Estranha o professor Madureira e Pinho a lacuna, em que neste particular incorre o meu trabalho. Não a autorizam (diz ele), nem o exemplo das legislações mais conceituadas, nem fundamentos de cunho doutrinario. A omissão é tanto mais censuravel, quanto é na maneira de regular os crimes políticos que o código criminal revela a diretriz do Estado em face das liberdades individuaes. Só, portanto, motivos de oportunidade, que não podem prevalecer sobre os outros, mais ponderosos, poderiam explicar o silencio do projeto.

Tem razâo, até certo ponto, o autor da objeção.

Obedece a imperativos de ordem prática o rumo seguido pelo projeto. O código é por sua natureza uma lei destinada a perdurar. Não ha como deixá-lo á mercê das circunstancias ou imposições do momento. Ora, são extremamente variaveis, no espaço e no tempo, as modalidades que assume e a maneira por que se considera e pune a criminalidade política. Sirva de amostra a nossa própria legislação. Votada a lei n. 38, de 4 de abril de 1935, viu-se o poder público na contingencia de modificá-la pela lei n. 136, de 14 de dezembro seguinte, que, por seu turno, foi alterada sucessivamente pela lei $n$. 244, de 11 de setembro de 1936 e pelos decretos-leis n. 88, de 20 de dezembro de 1937, e n. 431, de 18 de majo de 1938. Ora, manifestamente incompativeis com a estabilidade, que deve ter o código, são essas constantes variações determinadas pela necessidade de atender á defesa do Estado.

Trata-se, além disso, de criminalidade bem diferente da criminalidade comum, de que particularmente se ocupa o projeto. Tanto assim, que reclama outras penalidades, outras formas processuaes, outro aparelho judiciario. Sendo especiaes as penas, os tribunaes, o processo, especial deve ser a lei que define taes crimes. 
Não se me averbe de incoerente, por haver contemplado no projeto os delitos contra a economia pública, a instigação a delinquir, a resistencia e outras figuras delituosas, tambem previstas nas leis vigentes de segurança nacional. E' que, passadas as circunstancias anormais, em quc essas leis foram elaboradas, tudo aconselha sejam taes crimes julgados pelos tribunaes comuns, de acordo com o processo comum.

4) - O dr. Prudente de Siqueira inquina de contrario "ao principio científico de que a imputabilidade dos menores é materia mais conducente a codificação especial" o fato de estar o assunto disciplinado no projeto.

Não se acha, todavia, em lide nenhum principio científico. Ha autoridades que pensam como o dr. Siqueira. Muitas, porém, que opinam de modo oposto. Entre nós, por exemplo, estão de um lado autoridades da craveira de Costa E Silva, e de outro estudiosos do quilate de AtaLibA Nogueira. Se alguns códigos relegan a materia para leis peculiares, diversa é a atitude da imensa maioria deles e de quasi todos os projetos de reforma. Tratando-se de questão, em que divergem legisladores e doutores, não ha fulminar em nome da ciencia qualquer das soluções em apreço.

Parece, entretanto, que, mencionando, como não pode deixar de mencionar, quaes os incapazes de imputação, deve o código, lógica e necessariamente, declarar o destino que os espera. Assim procedem todos em relação aos alienados e aos deficientes; assim hão de proceder com relação aos menores. 0 silencio com referencia a estes obrigaria ao silencio com referencia áqueles. Está visto que ao código criminal compete apenas indicar as linhas geraes do regime da menoridade, cabendo á legislação especial desenvolve-las.

Menos verdadeira é a afirmação lançada em termos categóricos de que, por força de "um criterio já integrado 
na conciencia universal", os menores "foram inteiramente postos á margem do direito penal", e passaram o ser "objeto apenas de medidas administrativas" Tenho deante dos olhos os códigos mais recentes: o italiano, de 1930, o uruguaio, de 1934, o peruano, de 1924, o chinês, de 1928, o suiço, que é do fim do ano passado. Consulto os projetos de reforma aparecidos ultimamente: o francês, de 1934, o argentino de 1937, o chileno, de 1938. Sirvo-me de Cosentinı (Code Pénal International, 1937, p. 69 e s.), para o conhecimento do que dispoem os codigos dinamarquês, de 1930. e rumeno, de 1936. Pois bem: todos eles estabeleceram, mais ou menos minudentemente, o que ha a fazer dos menores, que pratiquem fatos qualificados como criminosos. Basta assinalar que o ultimo de todos, que é o suiço, consagra á materia todo um título, com 19 artigos.

5) - Entre os defeitos apontados por Altavilla estaria a carencia de epigrafes, que permitam nomear as variedades delituaes: "fica-se ignorando, p. ex., que as figuras definidas nos arts. 151 e 153 se chamam peculato e concussão" O defeito, se houver, será de somenos importancia e de fácil remédio. Mas não vejo francamente porque se haja de subdividir o código, com a multiplicação de secções e sub-secções que, na maioria das vezes, constariam de um só dispositivo, como no caso apontado.

6) - Ao mestre de Nápoles pareceram tambem sobremaneira complexos alguns preceitos, inçados de parágrafos e divisões, que chegam a dificultar a citação. Sirva de amostra (diz ele) o art. 311. A disposição em apreço ocupa-se do homicidio. Compreende cinco $\S \S$, em que se combinam penas diferentemente graduadas, conforme seja o crime culposo, preterintencional ou doloso, e, quanto a este, conforme tenham concorrido certas $e$ determinadas agravantes ou atennuantes. Em que pese á autoridade do contraditor, nada mais lógico e defensavel, uma vez que se 
trata de modalidades de um só crime, passiveis de penalidades diversas.

7) - $O$ eminente criminalista italiano qualifica injustamente de "híbrido conúbio" o fato do projeto haver englobado sob a mesma rubrica o duelo, o abuso de armas, o abandono de menores e enfermos, a exposição de infante, a omissão de socorro. Qual é, todavia, a rubrica? "Da periclitação da vida e da saude" Oferecem, ou não, todas as infracções que mencionamos a identidade especifica evidenciada pela epígrafe? Não ha quem possa negá-lo: todas têm de comum o risco ou perigo, a que sujeitam a saude e a vida alheias. Onde o hibridismo, se o caso não é de especies diferentes, e sim de entidades da mesma especie?

8) - Inexatidão de sistemática se afigura a Altavilla a inclusão na Parte Geral de causas extintivas, não de todos, mas de certos e determinados crimes, como o casamento do ofensor com a ofendida, nos delitos contra o pudor individual, e a rehabilitação nos delitos falimentares. 0 projeto não segue, efetivamente, neste particular o código de 1890 , e sim o projeto da Comissão Legislativa; porque mais logico e simples me pareceu enumerar as causas geraes e as causas especiaes de extinção, aquelas no corpo do artigo e as ultimas no $\S$ único.

9) - Censura igual da mesma origem provocou o capítulo referente á aplicação da pena, por mencionar as circunstancias que agravam e atenuam o crime.

Não vejo sinceramente onde está a cincada. No mencionado capítulo o projeto declara competirem ao juiz a determinação da qualidade da pena, quando a lei estabelece alternativamente mais de uma, e a determinação, dentro dos limites legaes, da quantidade da pena aplicavel. Quaes os criterios a que no exercicio desses poderes deve atender o juiz? Além das causas de aumento e de diminuição, fixadas para todos os crimes na Parte Geral e para alguns 
na Parte Especial, á personalidade do agente e á gravidade da infração. Como se poderá ajuizar da personalidade do agente? $\mathrm{O}$ art. 44 indica os elementos, que para tal efeito dever concorrer. Como apreciar a maior ou menor gravidade do crime? $O$ art. 45 declara as circunstancias que agravam o crime, quando não o constituem ou qualificam; o art. 46 as que o atenuam. Onde, sinão aí, dado o sistema do projeto, caberia especifica-las?

10) - Outra censura, tambem de Altavilla: muitas de taes circunstancias reaparecem na Parte Especial (art. 311 e outros), quando seria bastante uma referencia á Parte Geral, embora ai se estabelecessem criterios autonomos de aumento ou diminuição da pena. Se bem entendo a acusação, o de que sou acusado é de reproduzir por extenso na Parte Especial, determinadas agravantes e atenuantes, ao cominar penalidades diferentes para a mesma infração, quando bastaria uma simples remissão aos artigos da Parte Geral, em que se declaram taes circunstancias. Ora, a pratica demonstra quanto essas remissões dificultam o entendimento facil e imediato do texto. Basta um erro tipográfico, um algarismo errado, para turvar o sentido. Foi muito acintemente que, ensinado pela experiencia, o autor do projeto optou pela outra solução.

11) - Mais um reparo: a abolição do titulo "crimes contra a administração da justiça" leva ao erro grave de pôr na mesma plana de crimes contra a honra a difamação e a calúnia. Dois equívocos do eminente censor. Primeiro: uma das subdivisões do projeto se intitula "dos crimes contra a administração da justiça" (capítulo III do titulo II, que trata dos crimes contra a administração pública). Segundo: entre as infrações de tal natureza lá está no art. 179 a queixa ou denuncia caluniosa.

12) - Infundada tambem é a arguição, que se me faz de reunir "figuras heterogeneas, como a fraude comercial e 
a venda de cousas nocivas á saude (art. 375) no capitulo consagrado ao estelionato, abuso de confiança e outras fraudes" Simples desatenção do critico; porque lá está bem claro na disposição invocada: "fabricar, ou vender, ou expôr á venda, ou ter em deposito para consumo público, gênero alimenticio, que, embora não seja nociva á saude, tenha sido misturado ou acondicionado", etc. E' um caso tipico de fraude. Mas, quando se trate de substancia nociva á saude, o crime deixa de ser o de comercio fraudulento, e passa a constituir crime contra a saude pública, segundo se vê dos arts. 228-232, em que a nocividade aparece como condição existencial de cada uma das infrações aí previstas.

13) - Em dois pontos, porém, tem razão Altavilla. O fato de fornecer álcool a menor de 18 anos ou de ter menor dessa idade como empregado de estabelecimento, em que se forneçam bebidas alcoólicas, está deslocado no capítulo que se ocupa de crimes referentes á tranquilidade pública; e tambem o abuso da credulidade pública não constitue crime relativo ao trabalho. O segundo poderia sem dificuldade encartar-se na sub-divisão que trata do estelionato, abuso de confiança e outras fraudes; aquele caberia entre os crimes de periclitação da vida e da saude.

\section{IV}

\section{DE MERITIS}

Menos numerosas do que seria de esperar em materia tão controvertida, as reservas que manifestaram os criticos, no que respeita á substancia.

1) - Dizia o art. 2..$^{\circ}$ do ante-projeto: "Retroage a lei penal: I - que não mais considere o fato passivel de pena; II - que de outra maneira favoreça o agente" 
Pareceu a Costa e Silva ter "esse enunciado o grave defeito de não resolver ou não permitir ao intérprete que resolva, com apoio no texto legal, uma das mais importantes dúvidas que se levantam em materia de sucessão das leis penaes: a da eficácia ou ineficácia das leis intermediarias mais benignas"

Teria procedencia o reparo, se o dispositivo mandasse aplicar a lei nova ou posterior, ou usasse de expressão equivalente. Mas, se não me engano, quem diz que uma lei retroage afirma implicitamente a sua vigencia ao tempo da aplicação, e portanto, exclue a lei intermediaria, isto é, a que no intervalo começou e deixou de vigorar. A aplicação de preceito legal já revogado seria caso de ultratividade, e não de retroatividade.

Impressionou-me, porém, o fato de surgir a dúvida em espirito tão esclarecido como o de Costa E Silva. Procurei uma formula que tornasse impossivel a controversia. Inaceitavel se me afigurou desde logo a sugerida pelo meu contraditor: "Sendo a lei do tempo do julgamento diferente da do tempo em que o crime houver sido praticado, aplicar-se-á a primeira, sempre que de qualquer modo favoreça o agente". Inaceitavel, porque não prevê o caso de sobrevir ao julgado a "lex mitior" Não incorre na lacuna e impossibilita toda e qualquer vacilação a redação constante do projeto definitivo: "Retroagirá a lei vigente ao tempo da sentença ou de sua execução.

2) - Da parte de Costa e Silva, tão sóbrio em elogios, provocou o art. 3. ${ }^{\circ}$ este comentario: "Regulou o ante-projeto no art. 3. um assunto, teórica e praticamente, de superlativa relevancia: o da localização do delito. $E$ o fez, manda a justiça que se reconheça, com grande superioridade, em relação ao projeto SÁ Pereira”.

3) - A exemplo do projeto argentino e ao contrario do código Rocco, o ante-projeto se ocupava primeiramente 
do elemento subjetivo (dolo, culpa. .), e depois do objetivo (relação de causalidade. .), o que desagradou a Costa E Silva, para quem "neste ponto o código italiano é modelar"

Fiz-lhe a vontade ao redigir o projeto definitivo, embora seja indiferente, no ponto de vista da técnica legislativa, versar um assunto antes do outro.

4) - "O agente só responderá pelo evento que fôr efeito de sua ação ou omissão, diz inicialmente o atual art. 9.

Costa e Silva começa por afirmar que o ante-projeto imita ai "o seu modelo predileto", isto é, o código italiano. A imitação não seria condenavel, uma vez que, linhas adeante, o proprio critico não hesita em qualificar de "modelar" o trabalho de Rocco. Mas, de fato, não houve imitação. Compare-se com o texto acima transcrito o art. 40 do código fascista: "Niessuno può essere punito per un fatto preveduto dalla legge come reato, se l'evento dannoso o pericoloso, da cui dipende l'esistenza del reato non è conseguenza della sua azione o omissione" Basta o emprego da palavra "efeito", em vez de "consequencia", para-marcar a diferenca entre os dois dispositivos. Leia-se a proposito o que disseram Stopatto, Pozzolini, De Marsico subre a ultima dessas expressões, que não elimina, mas favorece as controversias em torno dos conceitos de "causa" $\mathbf{e}$ "ocasião"

Em seguida, lembra Costa e Silva que, durante os trabalhos preparatorios da codificação italiana, LoNGHI, FernI e outros entenderam supérfluo o dispositivo. Foram, porém, vencidos, com toda a razão. Como bem assinala GEnaro Marciano (Il Nuovo Codice Penale, 1932, p. 9), “i trattati hanno propugnate, in rapporto alle cause e concause del delitto (mediate, immediate, efficienti, determinanti, adeguate, prossime, remote) le dottrine più contradittorie, a traverso le quali l'interprete della legge o si disorienta o fa prevalere opinioni personali"; de modo que "l'avere fer- 
mato all'uopo criteri e norme indeclinabili $\dot{e}$ stato opera sapiente di legislazione" Reconhece-o tambem Giacomo DELitala, no trecho que Costa e Silva reproduz: "La regolamentazione del rapporto causale ha la sua ragione d'essere ed il legislatore che si rifiuti di farla manca al suo compito" No mesmo sentido, Nino Levi (em Il Codice Penale Illustrato, I, n. 122) : “L'art. 40 fissa il principio che, nel concetto della legge, tanto l'azione positiva (azione in senso stretto) como la negativa (omissione) può assurgere a causa obbietiva dell'evento; affermazione certo non superflua di fronte ai dubbi affaciati nella dottrina circa l'efficienza causale dell'omissione"

5) - Procurou-se fazer alarido em torno do $\S 10^{\circ}$ : "Faltar á obrigação de impedir o evento equivale a causa-lo".

Horripilou-se todo o sr. Hungria deante desse dispositivo, apodando-o de creação treatológica e preceito draconiano. Ora, o que provocou tamanho horror ao adversarjo) do projeto é tudo quanto ha de mais pacífico em direito criminal. E' precisamente o que dizem o código italiano, em seu art. 40, e o uruguaio, em seu art. $3 .^{\circ}$. E' exatamente o principio vitorioso, assim na jurisprudencia CONSTANTE do Tribunal do Imperio Alemão, como na doutrina alemã, UNANIME, ao que informa Nivo Levi (o c., p. 183, nota 2), com apoio em Entscheidung des Reichsgerichts in Strafsachen, XLVI, 337. e em WASchenfeld, Lehrbuch des deutschen Strafrechts, p. 95. E', por exemplo, o que servindo-se dos mesmissimos termos de que usa o projeto, professa Stoos (Lehrbuch, 1913, p. 111, apud Silvio Ranieri, La causalitá nel diritto penale, 1936 , p. 255 , nota 2), quando escreve que "PRODURRE UN EVENTO O NON IMPEDIRLO SI EQUIVALGONO". E', enfim, sem tirar nem pôr, o que, EM FACE DA ATUAL LEGISLAÇÄO BRASILEIRA, ensina Costa e Silva, "mestre dos mestres", no dizer do censor e tambem no meu pensar: "Ninguem contesta que certos crimes, que pressupoem para a sua existencia, a pratica de atos positivos por parte de delinquente, podem ás vezes ser per- 
pretados por omissões ou atos negativos. Em seu art. 208 nos proporciona o código um exemplo típico a propósito: o infanticidio pode ser cometido, tanto por meios ativos, como pela recusa á vítima dos necessarios cuidados. Para que por omissão, alguem pratique um delito comissivo, duas condições são imprescindiveis: a) que esse alguem tenha a possibilidade de agir, isto é, de evitar que o resultado previsto pela lei se realize; b) que lhe corra o dever, - dever jurídico, - de o fazer. QUEM, PODENDO E DEVENDO, EM VIRTUDE DE UMA OBRIGAC.ÂO LEGAL OU CONVENCIONAL, ACUDIR A UMA PESSOA QUE SE AFOGA, AO TOMAR BANHO EM UMA PRAIA MARITIMA, SE ABSTEM VOLUNTARIAMENTE, POR DOLO OU CULPA, DE O FAZER, RESPONDE POR HOMICIDIO. ESTA SOLUÇÀO SE ANTOLHARA' A MUITOS DUVIDOSA, PORQUE A RELAÇ.̃̃O DE. CAUSALIDADE ENTRE A ABSTENÇÃO E A MORTE DA PESSOA NÃO SOCORRIDA NÃO SE PATENTEIA AO PRIMEIRO EXAME, MAS SEM RAZÀO. ESSA RELAÇÂO EXIS'TE”. (I, p. 13). Porque essa relação existe, apesar de parecer a muitos duvidosa, é que deve declara-la de modo terminante o legislador.

Dar-se-á que o sr. Costa e Silva tenha comentado a legislação arcaica de Dracon, em vez do código penal da Republica dos Estados Unidos do Brasil?

Toda a atoarda vem, afinal de contas, de mero equívoco do censor. $O$ de que trata o dispositivo é, pura e simplesmente, de afirmar que na especie ha um nexo causal entre a omissão e o evento. Mas o reconhecimento da relação de causalidade não importa evidentissimamente, por si só, no reconhecimento da responsabilidade criminal do omitente em apreço. De fato, sabe toda a gente que, além do elemento material ou objetivo, a responsabilidade pressupõe o elemento subjetivo ou psicológico, isto é, o dolo ou a culpa. De sorte que se não houver dolo ou culpa, da parte do omitente, este não responderá pelo evento. Ainda mais: se o evento relacionado com a omissão realizar hipótese consi- 
derada pelo legislador sómente quando dolosa, e culposa fór a omissão, não existirá para o omitente responsabilidade penal, embora exista o nexo de causalidade.

Um exemplo: o guarda civil, que não impede, quando possa fazê-lo, o furto praticado sob suas vistas, é inegavelmente, pela inércia em que se mantem, causa do evento; mas, para verificar se ele responde pelo furto, terá a justiça de apurar se ele quiz assim favorecer a prática do crime, sendo nesse caso responsavel a título de dolo, ou se o fez por negligencia ou incúria, deixando então de responder pelo delito em questão, uma vez que perante a lei ha furto culposo. Outra hipótese: o ferroviario, que vê um obstáculo na linha e não lhe providencia a retirada, conquanto saiba que por ali passará um comboio e poderá suceder um desastre, será sem dúvida causa do acidente que se produzir. Isso não basta, porém, para que o julguemos criminalmente responsavel. Falta a indagação do elemento psicológico. Poderia o omitente prever que, deixando de remover o obstáculo, o descarrilamento se produziria? Estará em culpa. Sabia que no comboio viajava um desafeto e praticou acintemente a omissão, com o propósito de lhe pôr a vida em perigo? Responderá por dolo. Nada mais razoavel. Nada mais justo.

6) - Ainda com referencia ao $\S$ unico do art. 11, o sr. Hungria o entende excusado ou supérfluo, sob pretexto de que "do ponto de vista do direito, como pondera Ranieri, em Colpevolezza e personalità del reo, p. 62, não é concebivel omissão sem transgressão de um dever juridico"

Antes de tudo, supérflua seria, não a fórmula, mas apeuas a palavra jurídica, empregada para indicar a natureza da obrigação infringida.

Além disso, não é verdade que RaNieri desabone, por inutil, o dispositivo. Em obra posterior, repulsa a interpretação dada ás suas palavras por An'rolisei (Il rapporto causale, p. 201, nota 1): "Ma ho avvertito espressamente: "Il'aver il 
legislatore tenuto a dichiarare che il non impedimento giuridicamente doveroso di un evento equivale a cagionarlo, sembra voglia significare che la teoria dell'equivalenza delle cause ha qui una particolare applicazione" Così il mio pensiero è diverso da quelo che à sembrato a Antoliser"

Note-se, por último, que o projeto preliminar do código italiano não exigia expressamente a juridicidade da obrigação. Isso porque, segundo se lê na Relazione, e o censor reedita, "quando in una legge si parla di oblighi, è evidente che può trattarsi soltanto di obblighi giuridichi" Mas, consoante assinala G. Marciano (o. c. p. 19), "sulle premure di molti il legislatone, ad evitare equivoci, s'indusse ad inserire nel testo del Codice la parola giuridico"

7) - $\mathrm{O}$ ante-projeto consagrava dois $\S \S$, o $2 .^{\circ}$ e o $3 .^{\circ}$, do artigo de que me venho ocupando, ás causas antecedentes, simultaneas e supervinientes e á interrupção da causalidade. O sr. Costa e Silva chamou a atenção para as controversias, que têm suscitado os dispositivos correspondentes do código italiano. Convenci-me do deslize em que incorrera, e refundi inteiramente o preceito no projeto definitivo. A fórmula atual não despertou, por enquanto, objeção ou reparo. Acha que neste lance andou bem o projeto Enrico Altavilla, que dentre os críticos foi o unico a pronunciar-se a respeito.

8) - Duas glosas provocou do sr. Costa E Silva o presente art. 10.

Primeira: compete á doutrina, e não ao legislador, a definição do que seja crime consumado; e é o que se vê dos codigos modernos mais perfeitos. Para afirma-lo, porém, será preciso dar por inexistente ou de valor somenos o codigo italiano, tido e havido pelas autoridades mundiaes em materia penal como um dos maiores monumentos legislativos da idade contemporanea. Nada tem de inutil a noção de crime consumado, uma vez que dela decorre logicamente a de tentativa. Este, aliás, é um dos pontos, em que o projeto merece o valioso aplauso de Enrico Altavilla. 
Segunda: a cláusula "por circunstancias acidentaes", que o ante-projeto transplantara do projeto da Comissão Legislativa, parece menos satisfatoria do que a fórmula tradicional "por circunstancias independentes da vontade do agente"

De acordo com a sugestão, foi refundido o dispositivo.

9) - O ante-projeto declarava nâo punivel a tentativa, uma vez que o agente desistisse espontaneamente da execução do crime. Obtemperou Costa E Sirva, transcrevendo a lição de Alimena, que bastaria a voluntariedade do ato, porquanto seria de boa política receber com simpatia a desistencia, quando voluntaria, sem indagar dos motivos que a determinaram. O projeto definitivo atendeu á ponderação.

Ainda a propósito da desistencia voluntaria escreve ALTavilla: "Depois de ter dito no art. 10 que o crime se herdado quando a execução já iniciada se não consuma por circunstancias independentes da vontade do agente, manda no artigo imediato que se punam os atos anteriores que por si mesmos constituem delito, quando o agente desistir voluntariamente da execução ou fôr impossibilitado de consumá-lo" Não compreendo (acrescenta ele) como essa impossibilidade de consumação divirja da falta de consumação por causas estranhas á vontade do agente. Mas o projeto não exime de pena o agente, quando "fôr impossibilitado" de consumar o crime, e sim quando "lhe impossibilitar a consumação", o que é cousa muitíssimo diversa. Considera assim a hipótese da tentativa exaurida, que se balda pela intervenção ativamente impeditiva do agente. E' o caso do chamado arrependimento "ativo", como dizem os alemães, ou "operoso", como dizem os italianos, e que se não confunde com a simples desistencia.

10) - A conceituação do crime doloso abriu margem a mais sérias controversias.

Costa e Silva limitou-se a dizer que a noção constante do projeto é "sem dúvida verdadeira", mas, por insuficien- 
te, "deixa insoluveis as questões que se agitam a propósito da delimitação do dolo" Contra acusação de tal maneira indefinida não ha defesa possivel.

O dr. José Prudente de Siqueira envolve na mesma condenação a forma por que o projeto procura definir o dolo e a culpa, adotando, quanto a esta, a doutrina subjetiva, e, quanto áquele, a da intenção ou vontade, "muito embora de ha muito repudiadas"

Repudiadas, pergunto eu, por quem?

Pelos códigos mais recentes? Não. Conservam-se fieis á doutrina da intenção ou da vontade, no que respeita á definição do dolo, o código espanhol, de 1928, o italiano, de 1930 , o uruguaio, de 1934 , o romeno, de 1936 , o suiço, de 1938, os projetos francês, de 1934, argentino, de 1937, e chileno, de 1938.

Pelos juristas nacionaes? Tambem não. Tanto assim que o dr. Siquerra apresentou a seguinte conclusão á Conferencia Brasileira de Criminologia, reunida no Rio de Janeiro em 1936: "Deve ser adotada para a conceituação do dolo a teoria da representação, em vez da teoria da vontade, que o projeto consigna" E a conclusão foi rejeitada pela maioria de 29 votos contra 2 , entre os quaes o do autor da proposta.

Pela maioria dos mestres estrangeiros? Não ha quem possa afirma-lo. Na propria Alemanha, onde o dr. Siqueira esclarece que "a melhor teoria, a da representação" tem a aceitação "quasi unânime", Frank, invocado por S. S., assegura precisamente o contrario. E', pelo menos, o que informa Koenler. Depois de apreciar o projeto Rocco, de que o codigo italiano é neste lance reprodução literal, o professor da Universidade de Erlangen escreve (Il progetto Rocco nel pensiero giuridico contemporaneo, 1930 , p. 216) que "in Germania il concetto di colpevolezza viene inteso dalla dottrina dominante allo stesso modo" $\mathrm{E}$, em nota, ele cita, em abono dessa afirmativa, Frank, Strafgesetsbuch, $18{ }^{n}$ edição, nota II, 3 , do $\S 51$ 
De "erro imperdoavel" averba S. S. o fato dos^últimos projetos brasileiros fazerem "depender da conceituação do dolo o evento como seu elemento estrutural"

Onde está a erronia tão grave que não merece perdão? "Nos embaraços causados á qualificação dos delitos formaes". Nisso. Exclusivamente nisso. Salta aos olhos que a falta é demasiado minúscula para castigo tamanho.

Tudo vem do conceito que S. S. forma de "evento" Não direi (a vida me ensinou á mingua de outras cousas a humildade) que S. S. esteja errado. Direi apenas que se trata de conceito muitíssimo discutivel. Acrescentarei que, se porventura se tivesse equivocado, faria jus a todos os perdões. Porque, segundo atesta um dos criminalistas que por último versaram o tema dificilimo, reina, a propósito, nas esferas jurídicas, a mais estridente diversidade de juizos. Ha quem confunda (são palavras dele) o evento com a ação, o fato, o efeito do fato, a injuridicidade, o objeto do crime, a periculosidade, o simples dano e perigo, as circunstancias ou condições da punibilidade.

A distinção antiga entre crimes formaes e materiaes não tem escapado á crítica. Von Liszt chama-lhe duramente um contrasenso. Não menos terminantes se mostram Aifredo Rocco, Massari, Battaglini, Levi, entre os italianos, e, entre os alemães, von Hamel, Janka, Birkmeyer e outros. Alisto-me entre os discípulos desses luminares. Crime sem evento, isto é, sem dano ou lesão, ou sem perigo de lesão ou dano, é cousa que se não concebe; porque, na falta de evento assim entendido, desaparece a razão jurídico-penal da incriminação, e portanto, não existe crime.

Acresce que a análise descobre a existencia de um evento danoso ou perigoso e de um sujeito passivo primario (pessoa singular ou coletiva, Estado, etc.) nos chamados delitos formaes. Demonstrou-o Orfeo CecchI, em monografia consagrada ao estudo da materia (Teoria dell'evento nel reato, 1937, p. 49-55), defendendo a seguinte conclusão: “O evento se verifica, assim nos delitos formaes, como nos ma- 
teriais. E' de se notar sómente que nos primeiros coincide cronologicamente com a ação ou omissão (fase inicial), e nos segundos se realiza em fase temporalmente destacada e diversa (fase sucessiva)"

Para o sr. Hungria constitue pecado mortal haver o projeto reproduzido, a exemplo do de Sá Pereira, "o conceito do dolus facti do código italiano, isto é, o dolo descarnado do elemento ético-jurídico" 0 modelo aconselhavel seria o último projeto alemão, em que triunfa a concepção normativa do dolo.

Trata-se, porém, de uma doutrina a caminho de cristalização. Reconhece-o um de seus adeptos mais ilustres, que é Eugenio Florian (Trattato, I, n. 339) : "La fase attuale dell'emento soggettivo è nell'idea di colpa normativa, elaborata con complicata finezza dalla dommatica tedesca, anzi in via di elaborazione" O conceito (diz Florian logo a seguir) é novo e atrevido. Tanto lhe falta a madureza necessaria, que, ao procurar defini-lo, não se entendem os seus partidarios. Quem o diz é Silvio Ranieri (Colpevolezza e personalitá del reo, 1933, p. 29, nota), invocando o testemunho de MezGer: "Se questa cosi detta concezione normativa della colpevolezza è oggi dominante in Germania, non è affato pacifica neppure fra quegli scrittori" Deante disso, nada mais restava ao projeto senão seguir o conselho de A. Koehler: abster-se de transformar em preceito de lei uma idea, enquanto não perfeitamente precisada e amadurecida.

Não é só. Embora vitoriosa na Alemanha, a teoria normativa da culpa não logrou a adesão dos juristas brasileiros, o que evidentemente deve ser levado em conta por quem se dispõe a fazer um código para o Brasil, e não para o Reich. Por 26 votos contra 5, inclusive o do autor da proposta, a Conferencia de Criminologia de 1936 rejeitou a conclusão que mandava adotar no projeto o conceito alemão, em lugar da fórmula italiana. O proprio Costa E Silva tão imbuido dos ensinamentos germanicos, não acompanha neste particular os seus mestres prediletos. Apreciando o dispositivo, 
que nos foi oferecido como paradigma, diz o criminalista patricio, no segundo volume de seu comentario, publicado em 1938, á p. 461, que o intuito da fórmula é simplificar a noção de dolo, mas que "de pôr em dúvida é que se consiga tão louvavel desideratum, sobrecarregando-a de novo elemento". Confirma assim a opinião que manifestara no primeiro volume, infensa á concepção normativa. Não afirma, nem poderia afirmar, porque seria supinamente ridiculo, que tal doutrina merece detido exame. O que a seu ver parece digna de ponderação é a assertiva de ser "iniludivelmente exigida pela nossa lei penal" isto é, pelo codigo de 1890, a injuridicidade subjetiva, o que é bem diferente.

11) - Um dos dispositivos mais severamente criticados por Costa e Silva é o que admite a figura do crime preterintencional. Não hesita o critico em lembrar a propósito uma frase grosseira de Beling. Que contraste com a linguagem de Koehler (em Il progetto Rocco, cit., p. 220 e s.), ao manifestar a sua dissidencia, declarando-se partidario da eliminação da mera responsabilidade pelo resultado!

Confesso que nenhum entusiasmo tenho pela preterintencionalidade. Mas pensam de forma diametralmente oposta os juristas brasileiros, que, na Conferencia de 1936, aderiram, por 26 votos contra 4, á conclusão do dr. NArcelio de Queiroz, assim redigida: “ $E$ ' uma lacuna (do projeto da Comissão Legislativa) a ausencia de disposição geral sobre pretenrintencionalidade, que não é justo só exista no delito de homicidio". Cumpre-me salientar que, de inteiro acordo com a Conferencia, estão o projeto argentino de 1937, o código uruguaio de 1934, e, a acreditarmos em Cosentini (Code Pénal International, n. 64), cujas citações não posso no momento verificar, os códigos cubano de 1936 e norueguês de 1902.

12) - Discordaram, tanto o sr. Costa e Silva, como o sr. Prudente de Srqueira, da noção de crime culposo, constante do projeto. 
Afigura-se a ambos que a definição é casuistica, e "tod” casuismo em materia legislativa é sinal de que o legislador não conseguiu formar uma idea geral, capaz de abarcar os casos não previstos". Ainda neste ponto o que faz o projeto é obedecer á opinião manifestada na precitada Conferencia pelos juristas brasileiros. Significativa maioria de 21 votos contra 5, entre os quaes o do dr. Sreceira, aprovou o substitutivo oferecido pelo professor Filadelfo Azevedo: "Deve ser mantida, quanto á culpa, a redação do código vigente, excluida a parte final, a respeito de arte e profissão" Dir-se-á naturalmente que nem sempre a verdade está com a maioria. Responderei que com a Conferencia estão na especie os mais recentes códigos e projetos, com exceção apenas do suiço. E' o que testemunham os codigos italiano de 1930 e uruguaio de 1934, e os projetos argentino de 1937 e chileno de 1938.

Observa ainda Costa e Silva que na inobservancia de determinação da lei ou da autoridade pode haver culpa, mas pode tambem não haver. Se bem apreendi o argumento, a resposta encontra-se nestas palavras de KoEHLer (o. c. p. 237) : "L'enumerazione "innosservanza di leggi, regolamenti, ordini e discipline" non deve essere intesa nel senso che la culposa ignoranza o violazione di prescrizioni siffatte renda penalmente responsabili di tutte le conseguenze che la violazione può produrre: sarebbe questa una responsabilità per il versari in re illicita. La colpa va invece referita soltando alla produzione di quello evento che può essere messo dell'agente".

13) - A propósito de culpa, escreveu o sr. Hungria que culpa com previsão do evento e culpa conciente lembram "calor frio" ou "escuridão-luminosa" E acrescenta: "Se se julgar possivel comprovar "in concreto" que o evento lesivo não foi querido, mas representado ao espírito do agente, será preferivel reconhecer-se no caso um estado psicológico intermédio entre o dolo eventual e a culpa, e a sua denominação justa é "dolo de perigo" Quem me vale, 
ainda uma vez, é Koenler (o. c. p. 238-239). Contra a concepção da culpa conciente como vontade de perigo, ele invoca a autoridade de Mohramann, v. Hippel, Binding, e desenvolve uma argumentação, que assim termina: "é giusto dunque che tutti i progetti abbiano evitato di sostituire alla colpa consapevole il dolo di pericolo"

14) - Depois de firmar o principio de que a ignorancia da lei penal não exculpa o agente, o ante-projeto admitia uma exceção inspirada no codigo peruano: poderia o juiz diminuir a pena, se a ignorancia fosse culposa, e o máximo da pena cominada para o crime não excedesse de 3 anos, quando privativa da liberdade, ou de 5:000\$, quando pecuniaria.

Costa e Silva lançou-me em rosto haver ficado a meio caminho, deixando de reconhecer ao erro de direito e ao erro de fato a mesma eficácia. 0 de que se devia acusar-me de abrir exceção perigosa ao principio tradicional: "ignorantia juris neminem excusat". Resolvi mante-lo, em todo o seu rigor, no projeto definitivo. Ponderando melhor o assunto, convenci-me, com efeito, de que se trata de uma dessas normas, em que nenhuma fenda se deve tolerar, por mínima que seja, sob pena de ve-la dilatar-se indefinidamente, dando passagem livre á torrente dos abusos. Só um caso merece atenção: é o dos selvícolas. Mas esse já está devidamente regulado alhures.

15) - Do erro de fato ocupa o atual art. 15.

Tres são as objeções que lhe desfecha Costa e Silva.

Primeira: em vez de "sobre o fato que constitue o crime", dever-se-ia dizer de preferencia, como os codigos uruguaio e polonês, "sobre as circunstancias constitutivas do delito", porque, para excluir o dolo, basta que o erro venha a recair em um dos elementos, que pode ser até de direito. Não vejo conveniencia na substituição da fórmula, que diz em substancia a mesma cousa que a outra, e tem sobre esta a vantagem de tornar bem claro que se trata do error facti. 
Segunda: parece a Koenler que a hipótese do erro de fato causado por dolo alheio deve ser considerada no capitulo da participação no delito, como se vê do projeto alemão e do codigo suiço. Questão secundaria e de solução meramente opinativa.

Terceira: o ante-projeto não regulava a materia da aberratio ictus, ocupando-se apenas do error in objecto. Era evidentemente um lapso. Corrige-o o projeto, dizendo no \& único do art. 15: "quando, por erro ou acidente" Fica assim consagrada expressamente a doutrina da unidade, vitoriosa na jurisprudencia nacional.

Fez-me carga o sr. Hungria por haver desprezado injustamente "a fórmula ampla e irrepreensivel" do projeto SÁ Pereira, ou, melhor, do codigo suiço, que aquele traduz literalmente: "celui qui aura agi sous l'influence d'une appréciation erronée des faits será jugé d'après cette appréciations, si elle lui est favorable" Respondi que faltava ao texto um requesito essencial: a clareza, a possibilidade de ser entendido á primeira vista. Não era apenas eu, que assim me pronunciava. Era tambem Costa E Silva, que a qualificara de "algo confusa" Era tambem, a acreditarmos nesse criminalista, a de v. Liszt e de BAumgarte, em trabalhos publicados numa revista, cujo volume e página ele cita com a habitual probidade. Em réplica, disseram que no seio da segunda comissão suiça as únicas vozes, que se levantaram para manifestar o temor de que o dispositivo viesse a gerar confusão, foram as de Lange e outro. o que, de uma parte, não invalida a asserção de Costa E Silva, com relação ao pronunciamento de v. Liszt e Baumgarde, e, de outra parte, demonstra que no seio da precitada comissão houve tambem quem não julgasse claro o dispositivo em debate.

16) - Quanto ao art. 13, pareceu a Costa E Silva condenavel, por superfluo, o inciso que declara não punivel aquele que praticar a ação ou omissão por caso fortuito ou força maior. Só em dois códigos do orbe civilizado se the 
deparou preceito identico ou análogo: no italiano e no mexicano. Vejo, com espanto, que o Brasil está excluido dentre os paises em que penetrou a civilização. Não diz o código penal de 1890 cousa igual ou pelo menos muito parecida com o que se lê no projeto, quanto, nค art. $27 \S 6 .^{\circ}$, declara que "não são criminosos os que cometerem o crime casualmente"? A França está ameaçada de receber o labéo de incultura, porque o projeto de 1934 não hesita em seguir o exemplo do código italiano, isentando de pena (art. 124) aquele que fôr constrangido a praticar o fato "por força maior ou caso fortuito que tenha tornado inevitavel a violação da lei penal" A Romenia já se encontra no index: ao que informa Cosentini (o. c. n. 115), o art. 134 do código de 1936 comete o mesmo crime contra a ciencia.

Em que pese aos adversarios do projeto, é de todo necessario e verdadeiro o preceito em questão. Leia quem se interessar pelo problema a excelente monografia, que em 1937 consagrou ao estudo de "Il caso fortuito nel diritto penale" o professor Arturo Santoro, e, ao terminar a leitura das muitas páginas em que ele multiplica os argumentos tendentes á comprovação da "não superfluidade de uma norma sobre o caso fortuito em materia penal" poderá ajuizar da facilidade com que entre nós se decreta ser coisa supérflua a regulamentação legislativa da materia. Não será com duas ou tres linhas apressadas que se terá como destruida a argumentação de A. Santoro.

Ao sr. Hungria se afigura particularmente intoleravel a neferencia á força maior. Pensa o contrario o professor Eugenio Florian, que segundo creio, não é de todo jejuno em questões penaes. Observa ele, com efeito, em seu conceituadissimo Trattato (I, p. 502, n. 394), que "si può anzi sogiungere che il concetto di coazione, ch'era originariamente globale e confusionario, sbloccandosi, determinava gli istituti della violenza (specialmente morale), dello stato di necessità, della legittima difesa, rimanendo all'infuori, a sopravvivere, un residuo, che s'identifica appunto con la forza 
maggiore" E explica: "In ipotese di forza maggiore, l'avvenimento preme sulla volontá dell'agente, pur sempre consapevole e vigile, e la trae irresistibilmente all'azione o la paralizza e la blocca inattiva (omissione) : cioè la forza maggiore agisce automaticamente, attraverso la volontà del soggetto: in un fiume, 'Tizio che fa il bagno, trascinato della corrente impetuosa, sbatte contra una barchetta leggera e la rovescia: colui che era nel natante annega" Outra hipótese: "il capitano d'un bastimento a vapore, per un guasto alla macchina perde il governo della nave, ed investe ed affonda una nave minore"

Porque o projeto alemão e outros codigos e projelos não aludem ao caso fortuito e á força maior? O silencio deles está esclarecido por Florian (nota 2 á p. 502) : "I motivi al prog. germanico (1925) notano appunto che statuendo il prog. non essere punible se non chi agisce volontariamente o culposamente, per ció solo la responsabilità per il caso é esclusa" No projeto brasileiro de 1938, porém, NÃO EXISTE DISPOSIÇÃO CORRESPONDENTE A' APONTADA.

17) - Não menos atacado foi o segundo inciso do art. 14 do ante- projeto, que considerava passivel de pena quem houvesse praticado a ação ou omissão "coagido por violencia física irresistivel ou ameaças acompanhadas de perigo atual"

Quanto á coação moral, reconheci desde logo que ela poderia entrar sem grande esforço no estado de necessidade, e suprimi no texto do projeto definitivo a referencia.

Não me convenci, todavia, da inutilidade da disposição, no que entende com a violencia física. Alega-se que dela não cogitam os codigos e projetos mais reputados dos últimos tempos. Abro o italiano que não ha como excluir da lista, e leio no art. 466 que "não será punivel aquele que tinha praticado o ato por ter sido a jsso constrangido por outrem, mediante violencia física a que não poderia resistír ou subtrair-se de qualquer maneira" Identicamente dispoem 
o projeto francês, de 1934, o art. 33 do código romeno, de 1936, o art. 19 do código polonês de 1932, o art. $20 \mathrm{n} .9$ do projeto chileno de 1938. Daí se conclue que o projeto brasileiro nasce tão "atrazado" quanto os mais recentes.

Escreve com relação ao codigo italiano Nino LEVI (Il Codice Penale Illustrato, I, n. 158) estas palavras, que se aplicam perfeitamente á disposição análoga do projeto: "la disposizione si potrebbe considerare superflua. se non fosse utile per l'opportunità di porre la premessa della disposizione del capoverso ("in tal caso, dal fatto commesso dalla persona costretta risponde l'autore della violenza") e per corrispondere alle esigenze di una disciplina sistematica e completa della materia risguardante $i$ vizi della volontà".

18) - Começa o atual art. 14 por dizer que não será punivel quem praticar a ação ou omissão, com o consentimento de quem possa validamente dispôr do direito ameaçado.

Pondera o sr. Costa e Silva que, desde épocas que já vão distantes, "o problema do consentimenta da vítima tem sido, no direito criminal, problema grandemente discutido" $\mathrm{Se}$, com efeito, consultarmos o primeiro volume do Codigo Penal comentado por esse criminalista, lá encontraremos á p. 173 e seguintes a exposição abreviada e a crítica sumaria das teorias que dividem os juristas: a que adota em toda a sua amplitude o principio traduzido na paremia "volenti non fiat injuria"; a que recusa qualquer valor a esse principio; e a que resolve o problema diferentemente, conforme se trate de direitos alienaveis ou inalienaveis, de bens jurídicos absolutos ou condicionaes, de crimes contra o individuo ou contra o Estado ou o interesse público, ou de delitos de ação particular ou de procedimento oficial. Não se trata, aliás, de uma dessas questões meramente acadêmicas, de que deva desinteressar-se o legislador. E' evidentissima a sua importancia prática. A sua atualidade, a urgencia de lhe dar solução legislativa repontam nas mais diversas manifestações 
da vida contemporanea. Basta recordar as gravissimas controversias, que se têm suscitado a propósito da eficácia do consentimento no chamado homicidio por compaixão, nas operações cirúrgicas, nos jogos desportivos. Como, sem afronta á evidencia, poderá alguem sustentar a superfluidade de uma solução legislativa de problema de tamanha importancia e em que são tamanhas as divergencias entre os doutores?

Dois caminhos se nos abrem: regular o caso na Parte Especial, a propósito de cada uma das figuras delituosas, em que o problema possa apresentar-se, e é o que fazem muitas legislações; ou procurar uma fórmula geral, que sirva de norma ao juiz na apreciação das várias hipóteses. Excusado será, encarecer, como o próprio Costa E Silva, em outro passo de sua critica, as vantagens do método generalizador.

E' o que faz o projeto, e censuram-no por isso.

Do que se pode dissentir é da maneira por que a norma está redigida. Alegar-se-á naturalmente que ela é vaga e imprecisa, pois que não esclarece quaes os bens ou interesses de que pode o titular validamente dispôr, e esse é o "punctum pruriens" da questão. Responderei com Florian (Tratt., I, n. 450, p. 533) que "il diritto penale essendo essenzialmente fondato su basi di diritto pubblico, questo requisito, nel quale si rispecchiano le esigenze dello interesse generale, rappresenta un limite, peró non definible a priori". Acrescentarei que, segundo se afirmou na discussão do projeto Rocco, "il legislatore penale non può arrogarsi il compito di fare l'elenco di diritti disponibili. La materia trova regole, limite, statuizioni in ogni ramo di diritto, privato e pubblico, scrito e consuetudinario, e l'interprete a tali fonti deve attingere, per decidere se il consenso, validamente manifestato, abbia efficacia discriminante".

19) - Dispõe o inciso imediato do art. 14 não ser punivel aquele que praticar a ação, ou omissão, em obediência a ordem emanada de superior hierárquico, no exercicio de 
suas funções, uma vez que a autoridade seja competente para dar a ordem e esta não seja manifestamente ilegal ou, por circunstancias especiaes, o executor não possa ter conciencia da ilegalidade.

Analisando o dispositivo, observa o sr. Costa E Silva que dissentem os doutores, sobre se a hipótese é "de justificativa, circunstancia que exclue a anti-juridicidade da ação ou omissão ou simples excusativa que dirime a responsabilidade do agente"; e que, diante da fraseologia do projeto, não é cousa facil asseverar a indole que nele tem a circunstancia da obediencia hierárquica" Em que pese a G. Vidal. L. Roux e outros, a questão me parece distituida de interesse prático para o legislador penal: a este só importa especificar as situações, em que o agente de uma ação ou omissão definida em principio como delituosa não está sujeito, por exceção, á pena cominada. E' o que faz o projeto; é o que fazem os codigos holandês, norueguês, dinamarquês, soviético e outros; é o que fazem, no testemunho de Florian, as legislações contemporaneas, em sua maioria, quando se limitam á declaração pura e simples da não punibilidade do agente, nos casos de legitima defesa, obediencia hierárquica, estado de necessidade. Evitam-se distante as controversias inúmeras, que se travam na doutrina, a proposito da natureza dessas e de outras circunstancias, que impedem a aplicação da pena. Qual seria a vantagem de dar solução legislativa a taes divergencias doutrinarias? Tem a palavra J. Roux: a fórmula "não ha crime nem delito. " insinua desde logo que o fato justificativo exclue ao mesmo tempo o ilicito civil e o ilicito penal; enquanto que a fórmula "é isento de pena. " esclarece que o fato deixa subsistir o ilicito civil e, portanto, a obrigação de separar o dano. Valerá talvez o argumento para os códigos criminais que disciplinam a responsabilidade civil do agente. Não, para aqueles que, como o nosso código de 1890 e o projeto, mandam seja a materia disciplinada pelo direito civil.

Termina Costa e Silva por afirmar que a obediencia hierárquica é relação de direito constitucional ou adminis- 
trativo, e que, assim, exorbita o legislador criminal, quando Ihe fixa as condições. Que condições? Aquelas, de que depende a isenção da pena, para o executor da ordem infringente da norma penal. Que a materia seja pertinente ao direito punitivo, não vejo, francamente, como se possa negá-lo, sem agressão á evidencia.

20) - Do sr. Costa e Silva mereceu reparo a maneira por que o projeto encara o problema da legitima defesa.

Inevitaveis são as discordancias em materia de tamanha complexidade. Assim é que pensa o contraditor andaria com acerto o legislador pátrio, se do código Rocco, indigitado mais uma vez para modelo, mutuasse "in totum" a conceituação da legitima defesa própria e de terceiro. Pois bem: N. JASINSKY, professor da especialidade na Universidade de Sofia e autor de uma das obras mais reputadas sobre essa causa de justificação, desenvolve critica impiedosa contra a fórmula italiana, que o criminalista patricio entende perfeita. A começar, pelo ponto de partida, isto é, pelo pressuposto de que o sujeito ativo da legitima defesa atua "constrangido" pela necessidade de se defender, o que ao mestre búlgaro se afigura "inexato e erroneo" A continuar, pelo modo por que o código Rocco define o objeto da legitima defesa, definição que ao crítico parece repreensivel. A seguir, pela tautologia, em que o texto incorre, ao indicar uma das condições existenciais da justificativa: "perigo atual de uma of ensa" significa, em última análise "perigo atual de perigo de determinada especie" A terminar, pela solução dada ao problema da dimensão na legitima defesa: com a exigencia pura e simples de ser a defesa proporcionada á ofensa, não esclarece o legislador se tem em vista a proporcionalidade entre a intensidade da ofensa e a intensidade da defesa, ou a proporcionalidade entre o valor do bem ofendido e o valor do bem do ofensor, que é sacrificado pela repulsa. Aí estão dada menos de quatro dentre os motivos, por que o ilustre JAsinsKy averba de "erronea e insuficiente" 
a fórmula, que o não menos ilustre Costa E SILva reputa modelar. Nessa luta de gigantes não me atrevo (quem sou eu?) a tomar partido ou intervir. Quero apenas patentear as dificuldades invenciveis, em que se veria quem pretendesse reunir, em assunto desta natureza, o sufrágio de todos os mestres.

21) - Um dos extremos da defesa legitima seria, de acordo com o projeto, a ausencia de provocação "suficiente", da parte do agredido. Discorda do qualificativo o sr. Costa e Silva, por ser de sentido elástico e variavel. Mas o culpado é o proprio censor, que, em suas anotações ao Código atual ( $I$, p. 263), me ensinou o seguinte: " $E$ ' evidente que, para excluir a legitima defesa, não basta toda e qualquer provocação. Alguns códigos (como o espanhol, o argentino e outros) exigem que ela seja suficiente, e com este qualificativo querem significar que esteja em proporção com a agressão. Apesar de não expressa, essa limitação, perfeitamente racional, deve ser adotada em face do nosso código"

A propósito do mesmo requesito, receia Altavilla que ele suscite dificuldades de ordem prática, por serem diversos os fundamentos da provocação e da legitima defesa. Não ha razão para o temor. O projeto reproduz, em substancia, disposições que, oriúndas do código de 1830 , foram conservadas pelo de 1890. Não haverá futuramente, como nunca houve no passado, dificuldades na aplicação de preceitos de tamanha simplicidade e transparencia.

22) - O projeto foi tambem acusado de omitir, entre as condições objetivas da legitima defesa a agressão iminente. Falta procedencia á increpação; porque o dispositivo alude á agressão "atual", e "tal é a que começa a ser realizada, a que of erece possibilidade de continuação imediata ou a que se apresenta como próxima e iminente" Ensina-o Costa E Suva em seu comentario (I, p. 290); e essa é a "communis opinio", assim na doutrina nacional, como na estrangeira. 
23) - Várias as observações de Costa e Silva, com referencia á maneira por que foi regulado o estado de necessidade.

Uma, de menor importancia, está atendida no projeto definitivo: a colocação do instituto, dada a sua maior amplitude, antes do da legitima defesa.

Outras são de relevancia maior, e manda-nos a lealdade que lhes reconheçamos a procedencia.

Falta, com efeito, ao conceito da "necessitas" formulado no projeto um dos requesitos essenciais, que é o da proporcionalidade entre o fato e o perigo. Tal o principio firmado na Conferencia de Varsovia, de 1927: o bem ameaçado deve ser pelo menos equivalente ao bem sacrificado.

Estabelecida expressamente essa condição existencial, poder-se-ia ampliar a tutela a todos os bens, como fazem os codigos soviético, norueguês, polonês, suiço e o projet francês. Descaberia falar de "direito relevante", expressão que peca pela imprecisão.

Não tenho duvida em reconhecer que o dispositivo merece emenda.

24) - Dever-se-á, porém, abrir exceção em desfavor daquele, "de quem se possa razoavelmente exigir que suporte o dano?"

Alegou-se que isso constitue "o cerne da causa excludente da injuridicidade" Estranhei que, em se tratando de instituto conhecido desde a mais alta antiguidade, só agora se lhe tenha descoberto o cerne, o requisito primacial, a condição primaria. O proprio sr. Costa e Silva, de formação nitidamente germânica, não diz palavra a respeito, em seu livro que data de oito anos apenas. Tratase confessadamente de idea, que "tende" a fixar-se como postulado inconcusso. Tanto assim que só no projeto da Comissão Legislativa encontrara acolhimento. Enganei-me nesta ultima afirmativa: a idea surgiu pela primeira vez no projeto Stoos, e aí foram busca-la o código peruano e 
os projetos alemão e o da Comissão Legislativa. 0 fato é, porém, que, com exceção do suiço e do peruano, nenhum dos códigos modernos consagrou a novidade.

25) - Em varios de seus dispositivos o art. 15 sofreu impugnação da parte do sr. Prudente de Siqueira.

Para o autor da crítica, estaria em contradição com os "ensinamentos da ciencia e da experiencia" haver o projeto elevado aos 18 anos o periodo da inimputabilidade dos menores. Mas foi exatamente em obediencia a taes ensinamentos que o fizemos. Eis, por exemplo, o que ensina Florian na ultima edição do seu reputadissimo tratado: "Segundo pensamos, a maioridade penal é de se fixar em 18 anos, com alguma diminuição e certas variações, em confronto com os adultos, até aos 21" Sem tirar, nem pôr, o que determina o projeto. Nem se procure argumentar com as nossas condições antropo-mesológicas. Porque, antes de tudo, faltam estudos cientificamente orientados, que nos permitam conhece-las. E ainda porque elas não podem diferir sensivelmente das que prevalecem nos outros paises sul-americanos; e as legislações modernas do continente adotam concordemente o limite impugnado. Não é imputavel, diz o código uruguaio de 1934, aquele que executa o fato antes de completar a idade de 18 anos. Quando o delito fôr cometido por menor de 18 anos (preceitua o projeto argentino de 1937), aplicar-se-ão outras sanções, que não as aplicaveis aos adultos. Tambem o código peruano de 1934 isenta de pena os menores de 18 anos, submetendo-os a regime especial. O recentissimo projeto chileno, datado de 11 de maio de 1938, enumera, entre os carecentes de imputabilidade, o maior de 16 anos e menor de 18, "a não ser que o respetivo Tribunal de Menores declare tratar-se de delinquentes perigosos", restrição que, aliás, é de todo em todo indefensavel.

26) - Inimputavel, pelo projeto, é o surdo-mudo não educado. 
Os surdo-mudos podem ser classificados em tres categorias: ineducaveis, educaveis não educados e educados.

Os primeiros não oferecem dificuldade de ordem penal: a lesão é central e coloca-os entre os alienados.

Os segundos, da mesma forma: faltando-lhes, como lhes falta, o elemento indispensavel ao intercambio espiritual, são incapazes de imputação.

Os terceiros podem atingir certo nivel de desenvolvimento psíquico. Mas, por mais instruidos ou mais intimidaveis que sejam, não ha trata-los criminalmente como os normaes. Força é conceder-lhes diminuição da pena.

Tal a opinião comum entre os sabedores. Tal, notadamente, o parecer de Ruzz Maya. Tal, a diretriz seguida pelo projeto.

Que se alega em contrario? Que "o criterio de educação ou cultura não pode servir de norma para o legislador, cumprindo antes pesquisar se o grau de cultura obtido pelo surdo-mudo é de molde a habilitá-lo a determinar normalmente os proprios atos". Questão de palavras. Nada mais. O simples fato de ser educado o surdo-mudo está a indicar que ele tem a capacidade necessaria para compreender a injuridicidade da ação ou omissão, e de agir em consonancia com esse juizo.

Invoca-se em abono da critica a lição de SAltelli e de Falco. Mas o que eles dizem é que o código italiano não considera pessoa normal, completamente imputavel, o surdo-mudo, quando tenha recebido instrução. Tambem não o considera assim o projeto. Embora educado, o surdo-mudo é sempre um "minus habens", um deficiente. Aplica-selhe pena, porque é intimidavel; mas com diminuição e tratamento especial, porque aos normaes não deve ser equiparado.

27) - Entre os que não são passiveis de pena, e sim de medida de segurança adequada, inclue o projeto "aquele que, devido ao estado de alienação mental em que se 
encontre no momento do crime, fôr incapaz de compreender a criminalidade do fato e de se determinar de acordo com essa apreciação" Aquele (diz o artigo seguinte) que, "devido a grave anomalia psíquica, tiver minorada sensivelmente no momento do crime" a referida capacidade, será passivel de pena diminuida e da medida de segurança aplicavel.

Sou increpado pelo dr. Siquerra de estabelecer o criterio biologico puro para os inimputaveis e o criterio biopsicologico para os de imputabilidade restrita", incorrendo no mesmo desacerto do projeto primitivo de Sá PErEIRA, desacerto que eu proprio condenara em minha exposição de motivos. A injustiça da increpação é de bradar aos ceus.

Sabe toda a gente serem tres os processos, de que os legisladores se valem, para formular o principio da inimputabilidade criminal de causa patológica: o biológico ou psiquiátrico, o psicológico, o bio-psicológico ou mixto. Consiste o primeiro na menção das condições mórbidas que excluem a imputabilidade: é o caso do código francês, que fala pura e simplesmente de demencia. Alude-se, de acordo com o segundo, á falta ou carencia de predicados (liberdade moral, conciencia dos proprios atos, integridade da vontade, etc.), que formam o pressuposto de imputabilidade: é o rumo seguido pelo antigo código de Zurich. Aceito o terceiro, indicam-se alguns estados mórbidos do espirito; mas na explicação de Costa E SILva, firmam-se tambem alguns criterios psicológicos, para que o juiz possa apreciar o valor de taes estados: é o que fazem o código suiço e muitas dentre as legislações contemporaneas.

Pois bem: o código suiço, que, no dizer do sr. Siqueira, consagrou a sistema ou criterio mixto, único admissivel, declara a mesmissima cousa que o projeto de minha lavra. Basta cotejar o texto do segundo, acima transcrito, com o do primeiro, assim concebido: "aquele que, atingido por doença mental, idiotia ou grave alteração da conciencia, 
não tiver no momento de agir a faculdade de apreciar o caráter delituoso de seu ato, ou de se determinar de acordo com essa apreciação, não será punido".

Sem contravir á verdade, ninguem dirá que existe diferença de substancia entre os dois dispositivos; ou que o projeto brasileiro seguiu orientação oposta á da codificação suiça, apontada como paradigma.

A única divergencia é de redação. O código helvético fala em "doença mental, idiotia, grave alteração da conciencia". O projeto substitue todo esse fraseado por "alienação mental" E o faz com enorme vantagem, por isso que a fórmula substituida se aparta grandemente da perfeição técnica. Antes de tudo, excusado será falar de "idiotia", depois de ter falado de "doença mental" Porque doença mental é a idiotia; e basta o uso da expressão generica, para abranger todas as especies. Acresce que, referindo-se expressamente á idiotia, deixa o legislador á margem a imbecilidade e a debilidade mental, entidades que lhe são equiparaveis, no que respeita á imputabilidade, mas que com aquela se não confundem. Quanto á"grave alteração da conciencia", reportar-me-ei por brevidade á crítica de Leonidio Riberro e Murilo de Campos ao primitivo projeto Sá Pereira. Direi apenas, de relance, que a expressão é absolutamente imprecisa, abrindo ensanchas ás maiores dificuldades práticas na aplicação da lei. Como se comensura semelhante gravidade? Quando a alteração deixa de ser leve? Quando principia a ser grave? A solução fica entregue ao arbitrio individual.

O termo que reune a maioria dos sufragios é o constante do projeto: "alienação mental" Aconselham-no, entre nós, Afranio Pexoto, Franco da Rocha, Leonidio Ribeiro, Galdino de Siqueira; e na Argentina, Nerio Rojas, que o reputa insubstituivel. Nele se incluem, em verdade, todos os disturbios de ordem psíquica, transitorios ou permanentes, adquiridos ou congênitos, excludentes da imputabilidade criminal. 
O sr. Hungria arguiu sumariamente de incorreção o projeto, por haver acolhido o conceito da imputabilidade restrita, submetendo a um regime especial de custodia e tratamento, sob o nome de segregação, os semi-alienados.

Limitar-me-ei em resposta a reproduzir as palavras de Nerio Rojas: "Entre esos dos estados, alienación y normalidad, hay numerosos procesos psíquicos morbosos: no son sanos, ni alienados. Ni desde el punto de vista médico, ni del juridico, tanto en lo penal como en lo civil, está justificado negar la realidad de estos estados, vistos a diario en la prática. En cuanto a su interés medico-legal, ello es aun más evidente, porque la experiencia judicial demuestra que son precisamente estos casos intermedios los que plantean mayores dificuldades a los peritos y a los jueces. De acuerdo con eso, puede decirse que una ley que no tenga precisiones concretas sobre estos anormales es una ley incompleta" (Arquivos de Medicina Legal e Identificação, ano V, n. 12, p. 179). Por ocasião do primeiro Congresso Latino-Americano de Criminologia, celebrado em julho de 1938, na capital argentina, o problema foi versado por AlEJANDRo RAITzin: "La existencia de los semi-alienados. ha transpuesto hace ya tiempo la etapa de las discusiones teórias y doctrinarias. Ya nadie duda de su realidad demostrada por la experiencia psiquiátrica y los penetrantes estudios de la psicopatologia moderna. Existe un acuerdo casi unanime de que la semi-alienación agrupa un conjunto de individuos de un elevado indice de peligrosidad. Todo nos induce a pensar que ha llegado el momento de que la legislación penal nos ponga sobre todo en guardia contra los semi-alienados"

Tal o voto a que procura dar satisfação o preceito, a exemplo do projeto argentino e do código suiço, ambos de 1937, para citar apenas dentre as obras legislativas as mais adeantadas e recentes. 
28) - 0 art. 17 exclue expressamente das causas de isenção e diminuição da pena os estados emotivos e passionaes.

Elogiado por Afranio Perxoto e Prudente de Siqueira, o dispositivo provocou a repulsa de Jorie Severiano. Opuslhe desde logo esta contestação:

“Acusa-me s. s. de ter fugido á materia.

Que diz, entretanto, o ante-projeto?

Declara não passiveis de pena, e sim de medidas de segurança, o menor de 18 anos, o surdo-mudo não educado, o selvícola não adaptado, e todo aquele que, devido ao estado de alienação mental, em que se encontre no momento do crime, for incapaz de compreender a criminalidade do fato ou de se determinar de acordo com essa apreciação.

Declara passiveis de pena diminuida, e tambem de medidas de segurança, o menor de 18 a 21 anos, o surdo-mudo educado, o selvícola incompletamente adaptado, e o portador de grave anomalia psíquica, de que não resulte alienação mental.

Declära a seguir que não autorizam n'm a isenção, nem a diminuição da pena, os estados emotivos ou passionaes e a embriaguez pelo alcool ou substancia de efeitos análogos, salvo se devida a caso fortuito ou força maior.

Declara, por último, que atenua a gravidade do crime, quando não o constitue ou qualifica, a circunstancia de ter sido ele cometido "sob o influxo de violenta emoção produzida por ato injusto de outrem" Note-se: "quando não o constitue ou qualifica". Porque, ao tratar dos delitos contra a incolumidade pessoal (homicidio e lesões), o projeto estabelece penalidades mais brandas, verificado o concurso da referida circunstancia.

Deante disso, não se poderá afirmar que me recusei a enfrentar o problema. Encarei-o de frente e dei-lhe solução terminante. Solução acertada ou infeliz? E' outra questão.

- Assegura o sr. Jorge Severiano que neste lance o projeto é "simples cópia. do projeto Roccio" 
Não é tanto assim. Cópia significa, se os dicionarios não mentem, "escrito feito segundo outro, palavra por palavra; traslado, reprodução textual do que está escrito algures" Bastaria o fato de um texto ser redigido em italiano e o outro em português, para não se ter o direito de falar de cópia. Haveria, quando muito, tradução ou versão literal. Nem isso existe. De acordo com o texto italiano, "gli stati emotivi o passionali non escludono né diminuiscono l'imputabilitá" $O$ ante-projeto brasileiro tem a seguinte redação: "Não autorizam nem a isenção, nem a diminuição da pena: I - os estados emotivos ou passionaes; II - a embriaguez pelo alcool ou substancia de efeitos análogos, salvo se devida a caso fortuito ou força maior" Nunca se viu "cópia" que tanto se afastasse do original.

$O$ certo é que o ante-projeto se inspirou, não só no código italiano, como no projeto francês, de 1934 , e no primitivo projeto Sá Pereira. Dispunha, de fato, este ultimo, em preceito que a Comissão Legislativa suprimiu: "Não se diz inconciente aquele que, em estado de vigilia, obedece ás proprias paixões, instintos e sentimentos, embora momentaneamente exacerbados" E' o que, de maneira que me parece mais clara e mais incisiva, preceituà o ante-projeto.

- Para o meu nobre contraditor, o dispositivo italiano é natural em um regime de força, como o fascista; porquanto "o crime politico ou por paixão politica. aparece como o mais feio e o mais grave de todos os crimes" Perdoe-me s. s.. Nenhuma relação existe entre a actual organização da Italia e o tratamento reservado pelo codigo Rocco aos emotivos e passionaes. A prova é que, conforme já tivemos ocasião de acentuar, a idéa foi aceita por SÁ Pererra, quando o Brasil estava em plena democracia liberal. Democracia liberal, como as que mais o sejam, é a França; e o projeto francês, de 1934 , consigna a mesmissima providencia que o código italiano.

E' em verdade, a politica criminal, e não a politica no sentido vulgar, que repulsa a equiparação dos estados emo- 
tivos e passionaes á alienação mental. Haverá quem conteste os disturbios psiquicos resultantes da intoxicação aguda pelo alcool ou pelos entorpecentes? Ninguem ha, todavia, que se atreva a atribuir em materia penal, a mesma eficácia á embriaguez e ás psicopatias. Porque? Porque não o consentem as necessidades da defesa social: salta aos olhos o perigo que constituiria para a segurança coletiva, a impunidade dos ébrios. $\mathrm{O}$ mesmo sucede com os estados emotivos e passionaes. Não ha quem ignore que a emoção e a paixão podem comprometer o funcionamento "dos freios inhibidores da vontade", para me servir das expressões transcritas pelo douto opositor. Quem se atreverá, entretanto, a sustentar que a lei deve consagrar a inimputabilidade dos emotivos e dos passionaes? Quem haverá, entre nós, que desconheça os abusos clamorosos a que se tem prestado o art. 27, § 4..$^{\circ}$ do código de 1890 ?

Para que se não perpetue essa cumplicidade da justiça com o crime, é que, de modo expresso e positivo, declara o ante-projeto o que, em rigor, não precisava declarar. Descaberia aqui mais ampla discussão da materia. Subscrevo, por brevidade, a demonstração feita pelo dr. José Prudente DE Srqueira, em trabalho tão calorosamente elogiado pelo $\mathrm{dr}$. Severiano.

O que aconselha a doutrina vitoriosa no moderno direito criminal é que se leve em conta, no julgamento de criminosos da especie em debate, não o grau, mas a qualidade da emoção ou paixão. Tal o criterio adotado pelo ante-projeto, em seus arts. 4.7 e seguintes.

Respondem esses dispositivos á ultima das objeções do ilustrado causídico.

Diz ele que "generalizar em direito penal não é possivel, de vez que não ha dois casos absolutamente iguaes. Tudo depende do caso concreto" Não ha duvida. E' por isso mesmo que o ante-projeto manda seja feita pelo juiz a determinação da qualidade, em certos casos, e da quantidade da pena, em todos eles, tendo em atenção, não só a gravidade do crime, como a personalidade do agente. Na 
avaliação da gravidade do crime, deverão preponderar as circunstancias que entendam com a natureza dos motivos, o grau da culpa, a intensidade maior ou menor do dolo. No estudo da personalidade do agente ha considerar todos os elementos que contribuam para o conhecimento de seu temperamento e caráter.

Tanto basta para que do ante-projeto se afirme, como se escreveu do código italiano, que o legislador toma na consideração devida a paixão excusavel e a emoção justificada."

29) - "Responde pelo crime, como se o houvera cometido", dizia o projeto da Comissão Iegislativa, "quem tiver instigado o seu autor a cometê-lo, para ele concorrido ou á sua execução prestado assistencia" Dispõe o projeto: "Incorrerão nas penas consideradas para o crime, com as modificações constantes dos arts, 19 e 20", que, em certos casos, mandam aumentar a pena e, em outros, diminui-la: I - quem o houver diretamente resolvido e executado: II - quem tiver instigado ou determinado alguem a executá-lo. III quem executar o crime resolvido por outrem; IV - quem, antes ou durante a execução, prestar auxilio, sem o qual o crime não seria executado: V - quem de outra maneira participar da preparação ou execução do crime"

Não é exato que eu tenha assim reproduzido a "casuistica" da Consolidação das Leis Penaes. Onde, na Consolidação, dispositivo correspondente ao quinto inciso do artigo precitado? E onde, no projeto, cousa que se pareça com a Consolidação, na parte em que fala dos "que provocarem ou determinarem outro. por meio de dádivas. promessas, mandato, ameaça, constrangimento, abuso ou influencia de superioridade hierárquica"? E no tópico referente á promessa de auxilio ao criminoso para evadir-se, ocultar ou destruir os instrumentos do crime ou apagar os seus vestigios"? E no lance alusivo aos que "roubarem ocultarem cu comprarem causas obtidas por meio criminoso"? E na menção dos que "derem auxilio ou prestarem sua casa para 
reunião de assassinos e roubadores", e dos que "fornecerem instruções para a pratica do crime"? Onde, no projeto, a distinção entre co-autoria e cumplicidade constante da legislação atual?

E' igualmente constestavel a afirmativa de ser escorreita ou impecavel a fórmula do trabalho da Comissão Legislativa. Quem presta assistencia á execução do crime concorre inquestionavelmente para ele. a menos que "concorrer" tinha perdido a significação, que todos os dicionarios lhe atribuem, de cooperar, contribuir, comparticipar.

Muito preferivel seria a redação do projeto argentino: “Todos los que concurran moral o materialmente a la ejecución de um delito seran sometidos a las sanciones estatuidas para el mismo" Não adotei essa fórmula sintética, porque, segundo se vê do dispositivo imediato, precisava discriminar as varias modalidades de cooperação na prática do delito, uma vez que algumas dentre elas me pareciam passiveis de penas aumentada e outras de pena diminuida. Precisava discriminá-las, para traçar limites ao arbitrio judicial, a que dava ensanchas o projéto da Comissão, que se contentava em mandar fosse atendida na fixação da pena "a importancia da participação no crime".

30) — Diz o $\S 3 .^{\circ}$ do art. 18 que "no crime culposo, se o evento resultar da ação ou omissão de mais de um agente, cada um deles ficará sujeito á pena estabelecida para o crime"

Será excusado o dispositivo? Não o julgou inutil o projeto argentino, que se distingue notadamente por sua preocupação de síntese. Justificam-no da seguinte maneira Eusebio Gomes e Jorge Coll: "em um preceito, cuja necessidade nos foi demonstrada pela experiencia dos tribunais, consignamos de modo expresso que, no crime culposo, quando o resultado fôr devido ao concurso de varias pessoas, todas serão passiveis da sanção legal. Admitimos assim a teoria que reconhece como perfeitamente possivel o concurso de pessoas nos delitos culposos. As objeções que se fazem 
a essa doutrina (por Florian, entre outros) não nos convenceram".

Não é apenas na Argentina que o silencio da lei deu margem a vacilações e controvérsias. Tambem na Italia, onde, sob o imperio do codigo Zanardelli, "giurisprudenza e dottrina.. hanno pronunciato disparate opinioni sulla possibilità di concurso nei reati colposi "(Vanini, em Il Codice Penale Illustrato, I, p. 494), opinando negativamente Carrara, Pessina, Impallomeni, Magno, e pela afirmativa Stoppato, Alimena, Manzini, Massari. Tambem no Brasil: Costa E Silva, que não admite na hipótese a concorrencia criminosa, acentua que "a tese está longe de ser pacifica" (I. p. 81,); o que justifica de sobejo uma solução categórica.

31) - Imprecisa não é a definição do criminoso por tendencia: "aquele que demonstrar notavel perversão moral, por seu comportamento anterior, concomitante ou posterior a um crime doloso de perigo comum ou contra a integridade pessoal", uma vez que se não trate de portador de grave anomalia psiquica. Aí estão precisamente determinados os requesitos para se afirme a tendencia a delinquir: imputabilidade plena; autoria de crime doloso de perigo comum ou a incolumidade pessoal; comprovação da inclinação ao delito pelo comportamente anterior, concomitante ou superviniente ao crime.

Nada tem de vaga a expressão "perversão moral" Sabe toda a gente, para me servir das palavras de SAPorito, que "dalla zona dela criminalità comune si staccano due diramazioni divergenti: l'una percorre la linea della vera malatta. l'altra invece sulla linea del pervertimento morale" Ou como diz TANZI, "nen si può mettere in dubbio che anche all'infuori di ogni vera e propria psicosi. d'ogni reliquato morboso, esistono caso singolari di deficienza morale"

Nem se afirme que, neste passo, o projeto dá ensejo a que se exerça o mais descabelado arbitrio judicial. Basta, para desmontar a objeção, a série de cautelas, de que está cer- 
cada a declaração judicial da tendencia a delinquir: da sentença declaratoria proferida em primeira instancia haverá apelação ex-officio; e só produzirá efeito a decisão, quando, por dois terços de votos, fôr pronunciada ou confirmada pelo tribunal superior.

Se o dispositivo do projéto carece de precisão e favorece o arbitrio no juiz, que se dirá então do novo código suiço, onde se faz sumaríssima referencia (art. 42) áquele "que manifestar inclinação para o crime ou delito"?

32) - De maior profundeza são os reparos de Altavilé, com referencia ás noções de criminoso ocasional e criminoso por tendencia.

A' primeira, que vem do projeto da Comissão Legislativa, objeta-se, de uma parte, que a exigencia legal de ser momentânea a causa deixa á margem os passionaes, e, de outra, que não importa ser o crime cometido fato singular na vida do agente, uma vez que até o reincidente pode eventualmente classificar-se entre os ocasionaes. Respondo que, para mim como para a imensa maioria dos doutores, a começar por Lombroso e Ferri, os passionaes e os ocasionaes são tipos diferentes. Tem a palavra Florian (I, $\S 30$, p. 355): "Nel delinquente per passione, il delito appare come una tempesta, che trascina e travolge. Il delinquente d'occasione è um uomo quasi sempre normale, di scarsa energia volitiva, che si lascia afferrare e trasportare dall'opportunità momentanea.. In lui il delitto è attimo che fugge e non tornerà più: sono i delinquente primari poco o punto pericolosi, in regola esenti da difetti psichici" Nestes prevalecem os fatores exógenos ou externos. Naqueles os fatores preponderantes são internos ou endógenos.

Quanto á conceituação do criminoso por tendencia, a fórmula adotada pelo projeto é, de fato, em substancia, a de Gabriel Tarde. Pode ser imperfeita. Mas não encontrei melhor. Altavilla censura-a por englobar personalidades diversas, como sejam o delinquente instintivo e o louco moral. 
Mas, antes de tudo, o projeto brasileiro não se refere aos delinquentes instintivos, como fazia o projeto Rocco, em sua primeira fase. E, além disso, o dispositivo impugnado proibe de fórma iniludivel que se considerem criminosos por tendencia os portadores de disturbios ou anomalias psíquicas. Não me parece tambem que tenha razão o insigne professor italiano, quando censura o projeto, por não ter equiparado aos crimes dolosos de perigo comum ou contra a incolumidade pessoal os delitos sexuaes, "em que a verdadeira instintividade se revela" E' que (dizemo-lo ainda uma vez) não é á criminalidade instintiva que o projeto se refere. Criminoso por instinto é uma cousa: instinto (esclarece Rew) é impulso natural, sem noção do fim, sem deliberação prévia e muitas vezes sem conciencia daquilo que se faz. Tendencia a delinquir é cousa diversa: inclinação especial, predisposição particular, determinada pela indole malvada ou perversa do agente.

A materia se prestaria a largos desenvolvimentos, que seriam descabidos nesta súmula das criticas.

33) - Pergunta o sr. Hungria porque abandonei "o sistema perfeito do projeto Sá Pereira", no que entende com a multa.

São estes os dois principios fundamentais do trabalho da Commissão Legislativa: a inconversibilidade da pena pecuniaria em pena privativa da liberdade, e a fixação do "quantum" de acordo com a renda diária do condenado.

Quanto á substituição da multa pela prisão, no caso frequentissimo de insolvencia ou má vontade do responsavel, fui o primeiro a acentuar, na exposição dos motivos, que a solução é passivel de critica. Outra solução, porém, não encontrei na legislação e na doutrina, para evitar a impunidade dos insolventes e dos relapsos. Tanto isso é verdade que, sem embargo de seus defeitos, a conversão é adotada pela quasi unanimidade das legislações contemporaneas, desde a japonesa até a alemã, desde a peruana até a 
holandesa. Nenhuma se deixou impressionar pelo argumento sovadissimo de constituir o dispositivo exceção odiosa contra os pobres. Porque o argumento nos levaria ao extremo de estabelecer outra exceção, igualmente odiosa. contra os solventes, que só eles ficariam sujeitos á penalidade, nos casos em que esta fosse de natureza pecuniaria.

Quanto á fixação do "quantum", consoante as possibilidades do agente, direi que o projéto a consagra de modo inequivoco. E' o que se lê no art. 40: "a sentença que impuser a pena de multa fixar-lhe-á a importancia e marcará o prazo em que deve ser paga ao Tesouro Nacional, tudo de acordo com as condições econômicas do condenado e a maior ou menor gravidade do crime". Não é só: nos termos do art. 49 , poderá o juiz "autorizar o pagamento em prestações periódicas.. e permitir o pagamento mediante a prestação de serviços ou obras em estabelecimento público, reservado do salario quanto baste á mantença do condenado e a seus encargos de familia".

Seguimos neste particular a lição de Costa E Silva: "O sistema engenhoso do dia-multa. não passou do terreno da experiencia. São desconhecidos os seus resultados. A nós nos parece que, dada a tendencia hodierna de conceder aos juizes largo arbitrio na medida das penas, pode a individualização de multa ser perfeitamente ser conseguida, sem necessidade desse sistema" Nâo aceitou a idéa a própria Suécia, onde ela surgiu. Nem a Dinamarca, sem embargo dela figurar em varios projetos anteriores ao código de 1930. Ou muito me engano, ou a Finlandia é o unico país do mundo em que o processo vem sendo experimentado.

34) - Da maneira por que o ante-projéto disciplinava as medidas de segurança ocupou-se larga e encomiasticamente o sr. Madureira de Pinfo, em sua dissertação de concurso. A unica restrição, que formulou, desapareceu diante da redação definitiva, com a eliminação do dispositivo impugnado. 
35) - E' manifesto o engano de Altavilla, quando estranha a colocação do furto entre os crimes cometidos com violencia. A violencia á pessoa ou á cousa é exigida pelo art. 359, para caraterizar o crime de roubo, e não o do furto.

Em resumo: dentre os reparos que vieram á luz,

- sete despertou a redação do projéto, dos quais dois (n. 6 e 8) são atendiveis;

- treze suscitou a estrutura, sendo que um deles (n. 1) não mais prevalece e outro (n. 13) tem procedencia;

-- trinta e quatro provocou o merecimento dos dispositivos. Dessas objeções uma (n. 23) é aceitavel; cinco (1, 3, $7,8,34)$ perderam a razão de ser, diante do texto do projeto definitivo. Subsistem, portanto, vinte e oito, a que em verdade não é muito, sabido que o projeto encerra cerca de quatrocentas disposições, e atentas, sobretudo, a dificuldade e a transcendencia da materia. 